\title{
THE CHALLENGE OF POOR GOVERNANCE AND CORRUPTION
}

\author{
Susan Rose-Ackerman ${ }^{1}$
}

\begin{abstract}
1 ll political systems need to mediate the relationship between private wealth and public power. Those that fail risk a dysfunctional government captured by wealthy interests. Corruption is one symptom of such failure with private willingness-to-pay trumping public goals. Private individuals and business firms pay to get routine services and to get to the head of the bureaucratic queue. They pay to limit their taxes, avoid costly regulations, obtain contracts at inflated prices, and get concessions and privatized firms at low prices. If corruption is endemic, public officials, both bureaucrats and elected officials, may redesign programs and propose public projects with few public benefits and many opportunities for private profit. Of course, corruption, in the sense of bribes, payoffs and kickbacks, is only one type of government failure. Efforts to promote "good governance" must be broader than anti-corruption campaigns. Governments may be honest but inefficient because no one has an incentive to work productively, and narrow elites may capture the state and exert excess influence on policy. Bribery might induce the lazy to work hard and permit those not in the inner circle of cronies to obtain benefits. However, even in such cases, corruption cannot be confined to "functional" areas. It will be a temptation whenever private benefits are positive. It may be a reasonable response to a harsh reality, but, over time, it can facilitate a spiral into an even worse situation.

"Corruption" is a term whose meaning shifts with the speaker. It can describe the corruption of the young from watching violence on television or refer to political decisions that provide narrow benefits to one's constituents in the form, say, of a new road through the district. In short, speakers use the term to cover a range of
\end{abstract}


actions that they find undesirable. Because my topic includes both corruption and poor governance, I omit both morally corrupting activities, on the one hand, and run-of-the-mill constituency-based politics, on the other. I use the common definition of corruption as the "misuse of public power for private or political gain," recognizing that "misuse" must be defined in terms of some standard. Many corrupt activities under this definition are illegal in most countries-for example, paying and receiving bribes, fraud, embezzlement, self-dealing, conflicts of interest, and providing a quid pro quo in return for campaign gifts. However, part of the policy debate turns on where to draw the legal line and how to control borderline phenomena, such as conflicts of interest, which many political systems fail to regulate. As I outline below, one of the most important debates turns on the issue of "state capture" or the problem of creating open democratic/market societies in states where a narrow elite has a disproportionate influence on state policy. In those countries outright bribery may be low, but the system is riddled with special interest deals that favor the few over the many.

Researchers at the World Bank estimate that worldwide bribery totals at least $\$ 1$ trillion per year, just over 3\% of world income in 2002. The Bank staff extrapolated from firm-and household level data contained in their own country-level surveys so the number represents an order of magnitude with a large margin of error. ${ }^{2}$ It is an estimate of the volume of bribes, not the impact of corruption on economic growth and global income. If used to measure the costs of corruption, it assumes that the volume of payoffs is a good proxy for their economic effects. This, of course, need not be true. In economic terms bribes are transfers from one pocket to another and are not an accurate measure of corruption's impact. Rather, the economic costs are the distortions induced by these transfers. Those costs might be many orders of magnitude higher than the volume of bribes themselves, or they might, under some conditions, be lower. Bribes might be small in some countries because bribe payers have bargaining power and do not need to pay much to get large benefits. In other countries, public officials may be able to extort large payoffs that represent most of the benefits of the corrupt transaction. The estimate also ignores the role of corruption in increasing inequality and undermining support for democracy. Nevertheless, it provides a starting point from which to develop more fine-grained estimates.

Pointing to the magnitude of the problem, however, does not determine solutions. Because of the diversity of circumstances that produce corruption and poor governance, it is difficult to propose global approaches. Nevertheless, in what follows I make an effort, recognizing that improving governance in individual countries will require carefully tailored policies carried out with the hard work and personal commitment of those on the ground. Estimates of costs and benefits are obviously only rough guesses. However, it is important not to overlook reform possibilities in this area. Some reforms, if well designed and implemented, would have large benefits and 
very low costs. Unfortunately, they also have serious distributive effects, and those who gain from the status quo are frequently powerful economic and political actors capable of blocking reforms.

Cost-benefit ratios for other types of reforms will be distorted if they do not take corruption, self-dealing, and incompetence into account. Thus, the risks of corruption and weak administration need to be considered in assessing proposals, for example, to limit hunger, reduce violence, or improve education and health.

The options that I discuss fall into five categories: voice and accountability, procurement, revenue raising, regulation of business, and international efforts to limit high-level corruption in international business.

First, I summarize many successful examples of programs that improve accountability at the grass roots and argue that these cases provide lessons that can be applied elsewhere. Some cases, such as school financing in Uganda and public works construction in Nepal, suggest that relatively simple, inexpensive reforms can have large benefits if the political will exists.

Second, I recommend efforts to develop benchmark cost estimates that can help constrain procurement fraud and corruption. This would require coordinated data gathering efforts, but the giving the large cost distortions in contracting, sometimes up to $30-40 \%$, the gains could be large. Under some conditions, a state could combine benchmarking and citizen control to constrain waste and malfeasance.

Third, I consider reform of revenue collection through tax simplification and incentive-based reforms. Once again the net benefits of a well-designed program can be large, but the mixed record of past efforts suggests caution.

Fourth, I recommend the streamlining of business regulations based on data indicating the economic costs of "red tape." However, past work has only looked at the gains to business and had failed to consider the costs to society of eliminating regulations that provide social benefits. Thus policy must balance benefits and costs of regulations.

Finally, I discuss international initiatives to increase transparency in international concession contracts for natural resources and efforts to track down the assets of corrupt officials. The former option is also recommended in Paul Collier and Anke Hoeffler's (2004) paper on civil war for the Copenhagen Consensus. They estimate that it could provide multi-billion dollar benefits with minimal costs. Like the other options on my list, however, there is a dearth of actual experience with putting this idea into practice. One should follow an experimental approach to see what works and what does not.

This paper focuses on empirical evidence. It does not discuss theoretical work on the causes and consequences of corruption and poor governance. Those who want to pursue these issues further should consult my two books - Rose-Ackerman (1978) and (1999), a review article by Pranab Bardhan (1997), and the framework presented in Shleifer and Vishny (1993). These sources also include extensive references to 
the literature. To access current work, the World Bank Institute maintains a website [http://www.worldbank.org/wbi/governance] as does Transparency International (TI), an international nongovernmental organization committed to fighting corruption [http://www.transparency.org]. Several recent literature reviews are at the website of U4 Utstein Anti-Corruption Resource Centre at http://www.u4.no.

\section{Research on the Causes and Consequences of Corruption}

Several strands of literature demonstrate the benefits of corruption control and government reform. I begin with cross-country studies that try to explain the consequences of corruption and poor governance for economic growth and well being. The next section considers firm level surveys that explore the consequences of corruption for firm behavior. Next, I summarize surveys that provide a window onto individual attitudes toward and experiences with corruption and dysfunctional government. Then I turn the causal link around and review studies that seek to determine the causes of poor government and corruption. Finally, I introduce distinctions between administrative corruption, "state capture", and what Michael Johnston calls “power chasing wealth" (2002).

\section{A. The Consequences of Corruption and Poor Governance: Cross Country Research} Cross country research on corruption and governance is part of a growing body of research that looks for the institutional bases of economic growth. Measures of corruption and poor governance are correlated with per capita income and with the United Nations Human Development Index (HDI). Richer countries, on average, have less reported corruption and better functioning governments. ${ }^{3}$ The same holds true for countries with high levels of the HDI, a measure that includes measures of health and educational attainment as well as a logarithmic measure of income. Figure 1 shows the relationship between the HDI and the index of corruption developed by Transparency International. Very high levels of human development are associated with low levels of corruption (high numbers on the TI index). However, high levels of corruption (between 1 and 4 on the TI index) are associated with a wide range of middle to low levels of human development. ${ }^{4}$

These two stylized facts raise the possibility that policymakers should forget about governance and just focus on stimulating growth though standard economists' prescriptions. Under that view, marginal improvements in governance are of questionable benefit to poor and corrupt countries, and good governance is a "luxury good" that citizens will demand once they are rich enough to care. However, the available statistical evidence suggests that, correcting for other factors, poor governance is itself one of the reasons that some countries are poor and have low or negative growth rates. Kaufmann and Kraay (2002) confirmed this result and, in addition, 
found no positive feedback from higher incomes to improved governance. However, the issue remains contested. It seems plausible that both directions of causation hold. Demands for greater democracy, transparency, and integrity in government often become more insistent as per capita income rises. However, to the extent that corrupt rulers recognize this possibility, they have an incentive to limit prosperity to constrain such demands. Those who benefit from a corrupt status quo will try to impede reform. Improvements in human wellbeing seldom occur spontaneously but, instead, require government actions to complement private efforts. Governments that waste resources through malfeasance or inadvertence are a drag on growth and undermine the achievement of other goals.

: FIGURE 1

Mancur Olson's (1996) paper, showing that economic measures alone do a poor job of explaining the divergence in growth rates, spurred research on the importance of institutions. At around the time of the publication of that article, crosscountry data ranking countries' institutional quality began to be available, and researchers interested in economic development began to use existing political science measures of democratization. This spawned a large literature showing that "institutions matter." I cannot summarize that literature here except to say that I am sympathetic to Dani Rodrik's (2003) view that first-order economic principles do not map onto unique policy packages; furthermore, as he argues, igniting growth and sustaining it over the long term are two different things and may require different polices. I focus here on work that incorporates a measure of corruption, recognizing that these indices reflect not just the level and frequency of bribes but also capture the general quality of state-business-society relations.

Transparency International (TI), an international organization that advocates for the control of corruption worldwide has published cross-country data on corruption since 1995. TI collects data from a number of different surveys that mostly report business and expert perceptions of corruption in various countries. Some of the underlying data sources also include questions concerning the overall business environment_-asking about red tape, the quality of the courts, etc. Respondents rank the countries on a scale from excellent to poor. The annual TI indices are a compilation of corruption scores that average three years of data. They are ordinal rankings and do not provide measures of the volume of bribes, the incidence of corruption, or its impact. Because the underlying surveys included in the index vary from year to year, the data can not be used for time series studies. The World Bank (WB) has made use of the underlying indices that make up the TI index and has produced its own "graft" index using a different aggregation method and including more countries. It is highly correlated with the TI index. Most studies use one or the other of these indices. Although some countries change position from index to index and 
have different rankings in the TI and WB data sets, there is an overall stability to the rankings. Furthermore, if a country's score differs from survey to survey, one cannot tell if this is because of the use of different sources, changed underlying conditions, or shifts in perceptions. Thus, these indices are a rough measure of the difficulties of doing business across countries, but they should not be used to make precise bilateral comparisons between closely ranked countries.

Studies using these data have found that high levels of corruption are associated with lower levels of investment and growth and that corruption discourages both capital inflows and foreign direct investment (Graf Lambsdorff 2003a, Mauro 1995, Wei 2000). According to Wei, an increase in the corruption level from relatively clean Singapore to relatively corrupt Mexico is the equivalent of an increase in the tax rate of over 20 percentage points. The statistical result holds for East Asian countries as well as for the others in his sample. Acemoglu, Johnson, and Robinson (2001) find that when the risk of expropriation is high, growth rates tend to be low. Most measures of institutional quality are correlated, and in this case, expropriation risk and corruption go hand in hand so that the same association holds for corruption. Countries perceived as more corrupt pay a higher risk premium when issuing bonds (Ciocchini, Durbin, and Ng 2003). Corruption lowers productivity, reduces the effectiveness of industrial policies, and encourages business to operate in the unofficial sector in violation of tax and regulatory laws (Ades and Di Tella, 1997; Graf Lambsdorff 2003b, Kaufmann, 1997). Graf Lambsdorff (2003a, 2003b) finds that an improvement in a country's TI corruption score by one point increases productivity by $4 \%$ of GDP and increases net annual capital inflows by $0.5 \%$ of GDP. This means that if a country such as Tanzania could achieve the corruption score of the United Kingdom, its GDP would increase by more than 20\% and net annual per capita capital inflows would increase by $3 \%$ of GDP. Of course, such extrapolations are not to be taken strictly literally because the corruption score reflects all sorts of complex underlying conditions, but they do suggest the importance of the institutional environment to the achievement of economic success.

Highly corrupt countries tend to under-invest in human capital by spending less on education, to over-invest in public infrastructure relative to private investment, and to have lower levels of environmental quality (Mauro1997, Tanzi and Davoodi 2002a, Esty and Porter 2002). High levels of corruption produce a more unequal distribution of income under some conditions, but the mechanism may be complexoperating through lower investments in education and lower per capita incomes (Gupta, Davoodi, and Alonso-Terme 2002, Gupta, Davoodi, and Tiongson 2000). One study hypothesizes a U-shaped relationship. If corruption is very low or very high, inequality is low. However, in the high corruption case, everyone is equally poor. The empirical work, which omits the most impoverished countries, suggests that higher levels of corruption lead to increases in inequality, but the effect reaches a plateau at 
very high corruption levels associated with low levels of per capita income. Corruption levels help explain Gini differentials within Latin America, the OECD, and Asia, but they do not explain the large Asia \Latin American differences in Gini coefficients or the intercontinental differences in growth rates ( $\mathrm{Li}, \mathrm{Xu}$, and Zou 2000).

Corrupt governments lack political legitimacy (Anderson and Tverdova 2003). However, political supporters of corrupt incumbent governments, not surprisingly, express more positive views of the government. Presumably, this difference depends upon the individualized benefits that flow to these supporters. Surveys carried out in four Latin American countries (El Salvador, Nicaragua, Bolivia, Paraguay) in 1998 and 1999 showed that those exposed to corruption had both lower levels of belief in the political system and lower interpersonal trust (Seligman 2002). In Nicaragua, respondents were asked if the payment of bribes "facilitates getting things done in the bureaucracy." Interestingly, those who agreed that corruption gets things done were less likely to believe in the legitimacy of the political system (ibid. 429). Surveys of firms in countries making a transition from socialism provide complementary findings. Firms with close connections with the government did better than other firms, but countries where such connections were seen as important for business success did worse overall than those where political influence was less closely tied to economic success (Fries, Lysenko, and Polanec 2003).

In circumstances of low government legitimacy, citizens try to avoid paying taxes, and firms go underground to hide from the burden of bureaucracy, including attempts to solicit bribes. Using data from the World Values Survey and Transparency International, Uslaner (2003) shows that high levels of perceived corruption are associated with high levels of tax evasion with countries falling into two distinct groups. His survey data from Romania show that those who believe that one has an obligation to pay taxes have more trust in government. Similarly, Torgler's (2003) study of attitudes toward tax evasion in Central and Eastern Europe shows that when individuals perceived that corruption was high, they were less likely to say that people have an obligation to pay taxes. Thus, one indirect impact of corruption is to persuade people that it is acceptable not to pay taxes because government has been captured by corrupt officials and those who support them. As a consequence, corrupt governments tend to be smaller than more honest governments, everything else equal (Friedman, Johnson, Kaufmann, and Zoido-Lobaton 2000; Johnson, Kaufmann, McMillan, and Woodruff 2000). Thus in corrupt governments, the individual projects are excessively expensive and unproductive, but the overall size of the government is relatively small.

\section{B. Business Surveys on the Consequences of Corruption}

More nuanced results come from surveys that questioned businesses about the costs of corruption, red tape, and other constraints on doing business. The World Business 
Environment Survey (WBES), carried out between the end of 1998 and the middle of 2000 under World Bank auspices, questioned several thousand enterprises in 80 countries (Batra, Kaufmann, and Stone 2003). Figure 2 indicates the way constraints on business differ between OECD members and emerging economies. In the statistical work using firm-level data, a high frequency of corruption, financing difficulties, high taxes, and lack of government/business consultation each had significant negative impacts on firms' sales growth over 1997-1999 after correcting for other firm-specific features such as private ownership, size, age, and export activity. In countries with negative scores on all four measures, the average growth of sales of existing businesses was more than 10 percentage points less than in countries on the positive side on all four. Investment growth was affected by four factors as well, with policy predictability replacing lack of consultation. The same was true for the four significant variables in the investment equation. ${ }^{5}$ As the authors conclude, "While it may be difficult and take years to reform taxes, financing, corruption, and policy predictability, the evidence suggests that higher growth and investment are associated with such improvements". 6

: FIGURE 2

Other less comprehensive research studied countries as diverse as those in Asia, sub-Saharan Africa, and Central and Eastern Europe. Most of this work is broadly consistent with the WBES survey. Survey work in Asia by the World Bank demonstrates the way government effectiveness affects the investment climate and hence both the level of foreign investment in a firm and the firm's export orientation. In Bangladesh, China, India, and Pakistan firm export levels and foreign investment were higher where hassles and delays were low. Given the evidence that endemic corruption is "sand" not "oil", that is another way of saying that corrupt pressures are low. To help one understand the magnitude of the effects, the authors report "that if Calcutta could attain Shanghai's level of investment climate, the share of firms ...exporting would nearly double from the current $24 \%$ to $47 \%$, comparable to the coastal Chinese cities. Similarly, the share of foreign-invested firms would increase by more than half, from the current $2.5 \%$ of firms, to $3.9 \%$ " (Dollar, HallwardDriemeier, and Mengistae 2003: 7).

Svensson (2003) surveyed firms in Uganda. The level and incidence of bribery were positively associated with a firm's contact with the public sector for such matters as foreign trade, tax collection, and regulatory compliance. The level of bribes was a function both of the firms' ability to pay and of the expected cost of relocation. More corrupt firms had lower growth rates on average than others. This research suggests how corruption imposes differential costs on different types of firms and demonstrates how it is connected to the underlying policies of the government.

The most comprehensive survey work has been done in Central and Eastern Europe. The World Bank's two waves of surveys of the business environment in that 
region document the specific ways that corrupt officials and intrusive rules affect businesses and show how corrupt environments impose costs (Hellman, Jones, and Kaufmann 2003, Hellman and Kaufmann 2004, Johnson, Kaufmann, McMillan, and Woodruff 2000). There are broad differences in corruption and protection payments between Russia and the Commonwealth of Independent States, on the one hand, and Central Europe, on the other. Formally organized firms in Russia and Ukraine are much more likely to admit to hiding sales and salaries than firms in Central Europe (Johnson, Kaufmann, McMillan, and Woodruff 2000, Table 1). Wholly off-the-books enterprises are more common in Russia and Ukraine, and such firms hide all of their output from the authorities. Furthermore, firms in Russia and Ukraine report spending more time on government and regulatory matters than elsewhere (18\% and 25\%, compared with about $10 \%$ for the other countries)(ibid., Table 2 ). This may be a rough measure both of the degree of extortion to which firms are subject and of the degree to which firms can be exempted from rules if they curry favor with authorities. In Russia and Ukraine almost all firms that answered the question report making illicit payments, and they hide a high proportion of their sales. In Central Europe, a group of firms also operates both corruptly and partly off-the-books, but the practice is not so widespread.

Surveys demonstrate how firms manage to cope when the legal system is weak. Informal relationships built on trust and private sanctions exist but cannot easily bear the entire burden of maintaining business deals. Weak states produce widespread corruption, private protection rackets, and the flouting of regulatory and tax laws. The countries of Eastern and Central Europe vary in the security of property rights, and countries with more secure property rights have higher levels of new investment by established firms (Johnson, McMillan, and Woodruff 2002, 2000). ${ }^{7}$ The security of property rights is measured by the ability of the state to enforce its own rules impartially. In other words, the benchmark is not a libertarian state but one that provides services, regulates behavior, levies taxes, and operates an impartial court system. Property rights are less secure if bribery and protection payments are common and if the courts do not enforce contracts. Thus, corruption is not a route to a secure relationship with the state but opens up possibilities for extortion. Furthermore, if firms pay for protection, either to private mafias or to the police, this reduces the security of rights as well (Johnson, McMillan, and Woodruff 2002, Table 1). Trust in the state as a reliable actor seems important. Firms appear willing to substitute legal and impartially administered taxes for the uncertainties of bribe payments and the dangers of relying on private protection services (Friedman, Johnson, Kaufmann, ZoidoLobaton 2000). ${ }^{8}$

\section{Household Surveys}

Surveys of individuals sometimes ask about attitudes toward corruption and bribery. The results provide a counterweight to those who claim that entrenched corruption 
is acceptable to ordinary citizens. Interviews in a range of countries have found widespread popular disapproval of entrenched corruption (e.g., Anderson, Kaufmann, Recanatini 2003, Pasuk and Sungsidh 1994).

One particularly detailed study of four countries in Central and Eastern Europe provides some nuance (Miller, Grødeland and Koshechkina 2001, 2002). The research revealed that people disapprove of corruption even if they report engaging in it themselves. The authors conducted surveys and focus groups in four countries that cover the spectrum of transitional democratic and market institutions - from the relatively far-advanced Czech Republic, through Slovakia and Bulgaria, to Ukraine. Although experience with corruption varied markedly across the countries, the public's underlying values and norms did not differ greatly. A majority in each country expressed strong moral disapproval of payoffs, but, at the same time, a plurality of citizens in every country except the Czech Republic said they would pay a bribe if asked. The authors conclude that the basic problem is not a weakness in the underlying values of citizens and public officials but an excess of corrupt opportunities. Because of a concentration of corrupt opportunities in some areas of public life, the officials most likely to receive gifts or bribes are hospital doctors, traffic police, and customs officials. One hopeful finding — reproduced in table 1 was that people's attitudes toward bribery were affected by their perceptions of others' actions. Attitudes are not deeply entrenched but depend on situation-specific variables, such as one's perception about whether or not others are paying.

: TABLE 1

In diagnostic exercises conducted by the World Bank, surveys of this type have been used to narrow down anti-corruption efforts to areas of most concern to the population. However, although these surveys isolate pressure points where corruption is widespread, they do not measure the cost of bribery in terms of the inefficient or unfair allocation of public services or burdens. The next step in the diagnostic exercise, therefore, should be an estimate of the relative costs of tackling different types of corruption that affect daily life.

\section{Causes of Corruption and Poor Governance}

Given the costs of corruption and poor governance, reformers need to isolate the causes of these phenomena. Cross-country data permit one to obtain a broad overview of the underlying causes of corruption and weak governance. I have already mentioned the role of income and wealth as both a cause and a consequence of corruption. That association is clear in all the studies cited below. However, the simultaneity often is not well handled in the empirical work. Nevertheless, it seems possible to conclude, first, that poor governance contributes to low growth and to the other harmful outcomes noted above, and that weak underlying economic conditions 
facilitate corruption. The exception is a very poor country with weak institutions that is so badly off that there is little for anyone to steal.

Some studies find that trade openness and other measures of competitiveness reduce corruption (Ades and Di Tella 1999, Sandholtz and Koetzle 2000, Blake and Martin 2002), suggesting that societies with fewer rents to share are less corrupt. However, once again the causation is unclear; countries that do not favor corrupt firms may be able to establish a policy of open and competitive markets. Graf Lambsdorff (2003a), for example, finds that weak law and order and insecure property rights encourage corruption which in turn discourages foreign capital inflows.

Inequality contributes to high levels of corruption. In democracies in particular, inequality facilitates corruption, a result consistent with the state capture variant of corruption. The negative effect of inequality on growth may be the result of its impact on corruption taken as a proxy for government weakness (You and Khagram 2004). Here too the causal arrow goes both ways.

Historical and social factors help explain cross country differences. For example, Acemoglu, Johnson, and. Robinson (2001) use the mortality rates of European settlers as an instrument for the type of colonial regime put in place by the imperial power and find that it does a good job of predicting expropriation risk (and corruption levels) at the end of the twentieth century. La Porta, Lopez-de-Silanes, Shleifer, and Vishny (1999) consider legal origin, religion, ethnolinguistic fractionalization, latitude, and per capita income as determinant of a range of features of economic, social, and political life. Corruption, as well as other measures of institutional weakness, is worse in countries with higher ethnolinguistic fragmentation, few Protestants, and Socialist or French legal origins. (See also Sandholtz and Koetzle 2000, Treisman 2000.)

Colonial heritage, legal traditions, religion, and geographical factors seem associated with corruption and other measures of government dysfunction, but these are not policy variables that present day reformers can influence. The key issue is whether these historical regularities directly affect government quality or whether they help determine intermediate institutions and attitudes that present day policies can affect. In La Porta, Lopez-de-Silanes, Shleifer, and Vishny (1999) the historical variables are not always significant and become entirely insignificant when they add income and latitude. Thus, these historical patterns may operate through their impact on underlying institutional structures, not as direct determinants of corruption. If so, that may be good news for reformers so long as there are alternative routes to the creation of institutions that facilitate economic growth and high income (cf. Rodrik 2003). Latitude and history need not be destiny.

The impact of democracy on corruption is complex. High levels of economic freedom and lower levels of corruption go together as does an index of democratization (e.g., Sandholtz and Koetzle 2000, Blake and Martin 2002, Kunicova and 
Rose-Ackerman 2003). Governments with more female participation in politics are less corrupt, and this is consistent with survey evidence suggesting that women are more disapproving of corruption than men (Swamy, Knack, Lee, and Azfar 2001, Crook and Manor 1998: 42). Within the universe of democracies, features of government structure, such as presidentialism, closed-list proportional representation, and federalism, facilitate corruption (Kunicova, 2002; Kunicova and RoseAckerman, 2003; Treisman, 2000). ${ }^{9}$ Presidential systems that use proportional representation $(\mathrm{PR})$ to elect their legislature are more corrupt than other types of democracies. Many parliamentary democracies that elect legislatures by plurality rule have a heritage of British colonial rule, and many PR systems had French or Spanish rulers. Present day levels of freedom also have historical roots. However, if constitutional form, protection of rights, women's rights, and electoral institutions are important determinants in and of themselves, then countries have policy levers available even if they cannot change their histories.

A World Bank survey permits one to see how one country compares with others on a range of different factors (Kaufmann, Mastruzzi, and Zavaleta 2003: 363364). Although broad measures of corruption, government quality, and informal sector activity are strongly correlated, more fine-grained analysis often shows pockets of strength and weakness. For example, a study of Bolivia, using this survey, showed that it ranks poorly on several measures of corruption, judicial quality, and property rights, but rather well on standard macro-economic variables such as inflation, the exchange rate, and the quality of the central bank. Because Bolivia has had a low growth rate, the results suggest that getting the macro-economics fundamentals right is not sufficient. Institutional reforms are needed, and within Bolivia itself some public institutions score better than others and may provide reform models (ibid. 364-365).

\section{E. Crony Capitalism and the Links between Political and Economic Power}

The World Bank distinguishes between administrative corruption and what its calls "crony capitalism" or "state capture" Country-specific research on such countries as Russia, Albania, Indonesia, and Malaysia confirms the importance of the distinction. Administrative corruption includes the use of bribery and favoritism to lower taxes, escape regulations and win low-level procurement contracts. "State capture" implies that the state itself can be characterized as largely serving the interests of a narrow group of business people and politicians, sometimes with criminal elements mixed in. Even if the group with influence changes when the government changes, most of the citizens are left out. Michael Johnston (2002) proposes a richer taxonomy that includes political systems that manipulate private firms for personal gain. He calls this "power chasing wealth" as opposed to "wealth chasing power." The World Bank would probably put both types in the "state capture" category, but they 
may have different implications. For example, Russia may be moving from a case where private wealth controlled public power to one where political power dominates private wealth.

Favored firms may not have secure property rights in the legal sense but may be able to obtain favored treatment because of their insider status (Hellman, Jones, and Kaufmann 2003). The main risk facing such firms is the risk of a change in the political leadership. For example, in a study of Indonesia under President Suharto, Fisman (2001) used an index of the political connectedness of firms listed on the Jakarta Stock Exchange, dubbed the Suharto Dependency Index. He demonstrates that rumors about Suharto's health problems between 1995 and 1997 had a more negative impact on the share prices of firms with high levels of this index and that the differential impact was greater the worse the rumors. ${ }^{10}$

The World Bank and the European Bank for Reconstruction and Development show that, although administrative corruption is a problem throughout the former Communist states, state capture is a particularly serious problem in the countries of the former Soviet Union. In such situations the firms that do the capturing perform well, but overall economic growth suffers (Hellman, Jones, and Kaufmann 2003). Fries, Lysenko, and Polanec (2003: 31-32) document the differences between "captor" firms with insider status and "non-captor" firms. The former have higher growth rates of fixed capital, revenue, and productivity. Slinko, Yakovlev, and Zhuravskaya (2004) obtain similar results using data from the Russian provinces.

If top political figures themselves exploit their position for private gain, the effectiveness of government programs and the impact of foreign aid and lending suffer. Even if those with good political connections are also good economic managers, there is a long term risk that they will exploit their dominant positions to squeeze out potential competitors (Acemoglu 2003). This inequality of influence can extend beyond special treatment by the executive and the legislature to include the courts as well.

World Bank researchers define "crony bias" as the difference between the reported influence of one's own firm and business association, on the one hand, and the influence of those with close ties to political leaders, on the other. In a study using firm level data from the 2002 Business Environment and Enterprise Performance Survey on former socialist countries (BEEPS), Hellman and Kaufmann (2004) find that firm managers who believe that the state is unduly influenced by a narrow set of "cronies" are more likely to withhold taxes, pay bribes, and avoid using the courts. These actions then help keep state institutions weak. Bribery and extortion are mostly a problem for medium-sized businesses. Large dominant firms have close relationships with top political leaders so that mutually beneficial deals are possible. These deals are often harmful to the overall growth and prosperity of the country and undermine efforts to establish the legitimacy and trustworthiness of the state. 
In the geographically broader WBES survey of 80 countries there is a marked relationship between this measure of crony bias and survey responses on the size of the unofficial economy and the decree of democratic voice and accountability. A large unofficial economy indicates that the regulatory and taxation powers of government are low and that many firms cannot obtain outside financing because they are off the books. Low levels of voice and accountability suggest that the state is not responsive to its citizens' interests. Figures 3 and 4 present these results.

: FIGURES 3, 4

\section{Reform Proposals}

Research on the causes of corruption suggests ways to think about reform. First, the simultaneity between income and poor governance implies that purely economic prescriptions, taken alone, will not succeed either in promoting growth or in improving government performance. If, as Kaufmann and Kraay (2002) argue, causation flows mostly from corruption to low levels of income and growth, that conclusion is strengthened. Macro-economic policy prescriptions presuppose a well-functioning government, which is just what is lacking in corrupt countries. Similar problems of simultaneity exist for trade openness and inequality. Thus proposals to improve governance by concentrating on economic growth, trade openness, and reductions in inequality beg the question of how weak states could accomplish such fundamental changes. Second, history and latitude may be important, but they are givens, not policy tools. One needs to determine what they are instruments for and whether present day institutions are subject to reform whatever a country's history. Third, some features of political systems seem to promote honest and effective government: high levels of economic freedom, parliamentary structure, certain types of electoral institutions, and avoidance of private capture of the state and of state capture of the economy. Some of these statistical associations could be translated into particular policy proposals, but most of them are at a level of abstraction that is not easy to operationalize. Because the associations are statistical regularities based on cross-country research, I am reluctant to translate them into concrete proposals. My own emphasis is on middle-range proposals that concentrate on particular sectors and deal with government accountability from the bottom up. They are consistent with the broad empirical regularities outlined above, but they have a more selective focus.

The net benefits from some specific anti-corruption reforms seem to be quite high. Weighting benefits and costs more highly if they are experienced by the poor would only enhance the value of most policies. The problems are, first, setting priorities for a long term response and, second, overcoming the resistance of those 
who benefit from the status quo. Often even if the net benefits are large, the beneficiaries of the status quo are very powerful (Krastev and Ganev 2004, Fries, Lysenko, Polanec 2003).

The priorities I establish are based on my belief in some stylized facts and obviously depend on the truth of my empirical hunches. My empirical hunches are the following. (1) To the extent that low corruption is associated with beneficial outcomes - stronger growth, higher incomes, more equal income distribution - the explanation is not corruption taken in isolation but rather the close correlation between corruption and other measures of the way government functions. ${ }^{11}$ (2) From this, it follows that policies to improve government functioning should not primarily focus on enforcing criminal laws against corrupt dealings. These laws are a necessary background condition but will mean little unless accompanied by more systemic reforms. (3) Instead, one must consider the underlying institutions and habits of behavior that make corruption endemic in some countries and in some sectors but not others. (4) Although norms of behavior with historical and social roots influence the level of corruption, corruption is also a crime of opportunity that requires willing participants on both sides of the transaction. Variations in corruption within a country suggest that this is so. Thus, a country's legacy of corruption and poor governance need not be accepted as somehow determined for all time. The situation can be improved on a case by case basis. (5) Political and bureaucratic corruption occurs where greed and self-interest interact with government institutions. However, different factors create corrupt incentives in each case, and hence they need different policy responses.

Corruption, standing alone, is not comparable to hunger, disease, and violence among the world's problems. However, if the weak government capacities of which it is a symptom persist, targeted policies will fail in weak and dysfunctional states. This is especially so when a central state is under the control of a narrow group that does not operate in the interest of most of the population. Government may also be dysfunctional because it is excessively decentralized so that lowerlevel government officials can establish local monopolies free of oversight from higher levels of government. Rather than deal with the problem of concentrated political power head on, my options focus on ways to constrain and limit such power while at the same time acknowledging the value of a competent, well-functioning state.

The largely negative finding of a study of reform efforts in Eastern and Central Europe provides support for my approach (Steves and Rousso 2003). The WB and the EBRD carried out surveys of businesses in that region in 1999 and 2002. These are not panel studies, but they do shed some light on changes in the business environment over time. The survey results were matched with country level measures of anti-corruption initiatives that took the form of an index combining: (1) domestic 
legal reforms designed to increase transparency and accountability, (2) ratifications of anti-corruption conventions, and (3) specific anti-corruption actions such as publication of an anticorruption strategy and action plan and the establishment of an anti-corruption commission. In general, those countries that were least corrupt in 1999 adopted more of these reforms during the time period, partly in response to European Union pressure. Scoring high on the index, however, was not a reliable predictor of reductions in reported corruption and, unfortunately, was also associated a perceived increase in the problem. These results need to be interpreted with caution because they cover only a short period of time and one region of the world. They do, however, suggest that policies that simply raise awareness will not have the desired effect unless they are accompanied with more concrete, substantive changes in state/society relations.

Based on existing research and my own view of the way the parts of the good government puzzle fit together, I have isolated the following policies for further discussion. They are complements, not substitutes. Where possible I discuss studies that highlight successful policies and analyze failures. Some states are so dysfunctional that none of these reforms makes sense. My candidate for the most misguided World Bank project was one designed to improve President Mobutu's tax collection capacity in Zaire. Obviously, such a "reform" would not have improved social welfare. Leaving such deeply dysfunctional states to one side, the policies I discuss are: (1) improved oversight and participation by citizens and greater government transparency, (2) procurement reform, (3) improved revenue raising capacity, (4) improving the business environment by cutting unnecessary red tape, and (5) international efforts involving multinational firms and international organizations with a focus on asset recovery and greater transparency in international natural resource contracts.

Some reforms could, in principle, produce measurable improvements in productivity and economic growth; others, however, enhance government legitimacy and accountability and have no straightforward financial counterpart. However, as I demonstrate below, quantitative studies in individual countries demonstrate that empirical work can provide strong guides to policy. Thus, all of my specific policy proposals are accompanied by ideas for improving the quantitative bases for policymaking. This research usually will require primary data-gathering efforts, but in highly corrupt environments, the payoffs can be substantial.

In some countries corruption of the police and the army reflects the role of organized crime in society. That kind of "state capture" is obviously a major problem for the states involved and for those harmed by illegal businesses such as drugs and trafficking in humans and weapons. However, because it raises a host of issues specific to the control of organized crime and illegal businesses, I will not discuss this type of corruption here. ${ }^{12}$ 


\section{A. Oversight and Transparency}

"[C]orruption is an institutional system in which rights are dissolved in exchange for gifts...." Robbins (2000: 440).

Survey data from 80 countries suggests an association between low levels of voice and accountability and low levels of per capita income (figure 6). Furthermore, as figure 4 indicates, when voice and accountability are high, "crony bias" tends to be low. However, that relationship does not hold when a country moves from very low to low levels of voice and accountability. Thus, if reforms raise expectations through pure participatory strategies, they may produce disillusionment if not coupled with more fundamental changes. At this level of aggregation, however, one cannot make specific policy proposals. Instead, I move down a notch and consider the benefits of a particular type of citizen oversight and government transparency: local citizen involvement.

: FIGURE 6

The benefits of moving to more local control depend both on the effectiveness of such control and on how bad things are at present. There are two prongs to the development of a strategy. First, one must find programs and governments that are very wasteful in providing services or managing aid flows, and second, within that universe, one must select countries and projects suitable for managed decentralization. By this I mean, decentralization of monitoring and service provision along with centralized information flows and the enforcement of anti-corruption and anti-fraud laws.

Several detailed studies have examined the way local involvement in public programs can enhance efficiency and increase benefits. They show that it can be done, but also provide numerous cautionary tales of poorly designed programs. I concentrate on the conditions for successful decentralized programs, recognizing the need to guard against the capture of state structures by those seeking illegal enrichment. Careful studies of individual programs suggest that the benefits of improved integrity in local aid projects and public service delivery ranged from $100 \%$ to $400 \%$ in the cases studied. However, the more anthropologically informed work suggests limits to participatory models in hierarchical rural societies. Decentralization can be an invitation to local corruption and self-dealing if not managed effectively.

In Latin America reformers have made numerous attempts both to involve rural people in the design and monitoring of agricultural development programs and to increase the participation of city dwellers in government decision making. The rural development programs sought to improve the targeting of programs to the needs of farmers and to increase accountability to beneficiaries (Das Gupta, Grandvoinnet, 
Romani, 2000; Parker, 1995). The urban cases, of which the most famous is Porto Alegre, Brazil, had the explicitly political goal of increasing democratic participation in opposition to existing clientalistic structures (Abers, 1998. de Sousa Santos, 1998). The successful cases in both settings gave citizens better information about what to expect from government and developed their capacity to hold public officials to account. The result was a reduction in corruption and self-dealing.

The World Bank's surveys of public officials in Bolivia provide some statistical backing for the view that low corruption and high levels of transparency and "voice" are beneficial to the actual performance of government and help the poor (Kaufmann, Mastruzzi, and Zaveleta 2003: 380-388). A study based on 1200 interviews with public officials in many different national agencies and local governments demonstrated wide inter-agency and inter-government variation. Using simultaneous equation techniques, the study found that public service delivery is negatively associated with corruption and positively with the external voice of users and with transparency. Bribery and corruption are higher in more politicized units of government and in those with lower transparency and less meritocracy. Transparency is affected positively by voice and negatively by corruption and politicization. Municipal governments perform worse than central government agencies on average but do sometimes provide better access for the poor. Measures of civil service management and individual ethical commitments had no independent impact although they may obviously be associated with some of the other data (ibid.: 383). Figure 7 illustrates one result - the finding that higher levels of voice and accountability are associated with greater accessibility of the poor to public services (Kaufmann 2003: 24).

: FIGURE 7

Survey evidence and case studies of participatory programs suggest that they require a long-term commitment from established governments along with technical and organizational help. For example, case studies of USAID Community Partnership Grant Programs in South Africa found that successful programs had broad-based involvement combined with support from the incumbent local government. The one clear failure was when USAID worked with a defeated politician whose efforts were undermined by those in power (Adams, Bell, Brown 2002). Trevor Brown (2001) documented the importance of technical assistance in developing local government capacity in Ukraine and cites other supportive results from around the world. People who are not used to political power need time to learn how to exercise it responsibly. A 1998 study reports that over eighty Brazilian cites have begun to adopt some form of participatory budgeting (de Sousa Santos 1998). This suggests that one could review these efforts to see which ones worked and which failed. 
One positive examples comes from work by Ritva Reinikka and Jakob Svensson (2002, 2004a, 2004b). They document the severe leakage of central government funds meant for local primary schools in Uganda. One dollar of central government funds produced \$.20 in budget for local schools. Their study led to a simple, information-based reform that had positive results. Reform focused on publicity combined with better monitoring. After its introduction, one dollar expended by the center produced $\$ .80$ of local school funds, a 400\% increase. Nearly 75 percent of the improvement in the targeting of funds can be explained by a newspaper campaign to publicize funding levels so that parents would know what funds their children's schools were due to obtain (Reinikka and Svensson 2004a, 2004b). Importantly, parents were already organized and able to exert pressure. Mere publicity will not work in isolation. The study gives no estimate of the cost of newspaper advertisements and notice boards, but they must have been minimal. The most substantial costs were increased official monitoring and the time spent by parents in checking on the school budgets. Because $20 \%$ is still lost, the returns on a dollar of actual education spending would need to be at least $12.5 \%$ for the returns to the central government on the program to be $10 \%$. Before the reform, however, the returns would have needed to be $50 \%$ ! Thus, the program appears to be cost effective although it also has an upper bound-losses will never go to zero. A key feature of the Uganda case, however, is the existence of parent-teacher groups at the village level that can perform monitoring. In countries where such groups do not exist or where powerful local or regional actors can steal with impunity, more costly and complex interventions will be necessary. Even in Uganda, education may be a special case because it is a service used by school-age children on a daily basis, unlike, say healthcare, where demand is more episodic, and sick and injured users are vulnerable to exploitation.

Uganda provides a "best" case scenario. Conditions were very bad ex ante, and once research revealed the shortfall, a centralized information provision policy combined with better enforcement reversed the percentages. This reform does not answer the question of how much a country ought to spend on education but suggests that, with the reform, education spending will appear to be more productive. This result may lead to an increase in the budget. Suppose, just for the sake of illustration, that the extra costs of the anticorruption program are $\$ .10$ for every dollar of appropriated funds, then every $\$ 100$ of budget would produce $\$ 100-\$ 10-.2(\$ 90)=\$ 72$ of education spending, up 360\% from before the reform. Of course, as noted above, these are only pecuniary gains so one would also want to know how many resources were wasted hiding the fraud and the rate of return on education compared to the use of the diverted funds. At the very least, however, the distributive impact of the reform is in favor of children, many with low income, and the gains are very large if one takes as given the share of the government budget going to education. 
To perform a cost $\backslash$ benefit analysis of this reform, one would need an estimate of the rate of return to primary education spending in Uganda. Unfortunately, such data are not available. However, in wealthy countries returns to an added year of education are in the range of $8-12 \%$ in increased earnings for individuals. Because these estimates ignore public benefits from an educated citizenry, social benefits ought to be larger. Recent attempts to measure the impact of education on economic growth have produced disappointing results in the developing world, suggesting that years of education are not a good predictor (Easterly 2001: 71-84). Jere Behrman (2003) in a review article argues that older studies showing high returns to education in poorer parts of the world overstate the private and public returns to schooling. Perhaps the disjunction between the results for individuals in developed countries and cross-country studies lies in the fact that a year of schooling in a poor country may not mean much in terms of actual learning if corruption and self-dealing lead schools to operate poorly. Easterly refers to absent teachers and school officials who sell school supplies for person gain. Literacy levels would surely be higher if these illegal practices could be curtailed. The study in Uganda suggests that simple theft of resources by regional officials was the reason for underfunded schools. If theft is high, years in school may be a poor proxy for learning.

Other instructive cases concern the devolution of authority in Nepal, India, Bangladesh, and Indonesia. In Nepal and Karnataka, India, researchers estimated that the productivity of external aid funds doubled as a result of more local control. The programs were of direct benefit to local people - roads, irrigation projects. Thus, they had a reason to assure that funds were used effectively. However, research in Rajasthan and Tamil Nadu in India, Bangladesh, and Indonesia highlight the need to give careful consideration to local conditions to avoid failure.

In Nepal, a pilot program involved local people in the direct administration of a food-for-work program through information diffusion and a workable structure of monitoring. Standard practice involved national government guidelines for paying workers that were far above market wages. As a result, contractors with the national government, paid market wages and pocketed the difference. When control was transferred to a sample of villages in an experiment, they paid market wages and build twice as many miles of roads with the same budget. The result was a dramatic increase in the cost-effectiveness of aid programs and a large increase in client satisfaction. The costs were the time spent by the villagers in administering the program as well as the cost of technical assistance to establish the system. However, presumably there are corresponding savings at the national level where bureaucratic inputs could be reduced. The main issue in such cases is how to generalize the positive experience in an experiment to the country as a whole. Key questions about the relationship between local authorities and the national administration are not answered by positive experiences in a few villages. In fact, in Nepal efforts to expand 
the program met with resistance as national level officials and private contractors mounted resistance (Meagher, Upadhyaya, and Wilkinson, 2000).

In Karnataka, India, decentralization improved government performance and limited corruption according to fieldwork done in 1978-79 and 1981 (Crook and Manor 1998: 22-84). Public sector workers, especially teachers, worked harder because they were, in the words of one person interviewed, "under the supervision of the questioning public mind" (ibid.: 60). Absenteeism continued to be a problem, but those who did come to work performed better. Although the number of people involved in corrupt acts increased, they siphoned off fewer resources (ibid.: 61). Before decentralization "a large fraction" of funds was diverted. The Indian decentralization policy increased the number of officials (elected and otherwise) from over a score to 3000. This increased the number of potential bribe takers. However, the greater transparency of the political process limited the overall level of payoffs. A vigilant press, an active two-party system, and effective voluntary organizations contributed to transparency. For a given level of funding from the center, there was a large increase in micro-level infrastructure projects. The authors conclude that this increase resulted both from the preferences of local political actors for such projects and from a decline in corruption. Under the decentralization policy corruption took from 5 to 25 percent of local government funds with most districts falling in the 5 to 10 percent range. Only in 2-3 remote districts was the share 25 percent. This was a major improvement over the past. However, although overall corruption decreased, most people believed that it had increased because of the greater transparency of government operation (ibid.: 79).

On the down side, increases in local control do not necessarily increase transparency and accountability but might instead promote locally based corruption and even facilitate organized crime influence (Anderson, Kaufmann, and Recanatini 2003: 11, Das Gupta, Grandvoinnet, and Romani 2000, Gong 2002). In a worst case scenario, devolution enhances the power of local patrons and entrenched interests. For example, an interview-based study of forest management in the Indian state of Rajasthan demonstrated the way a de jure institution transformed into a stable system of extra-legal exchanges (Robbins 2000). Robbins reports the range of de facto prices for various uses of the forest and explains how personal connections interacted with payoffs to favor some individuals and families over others. As a result, many of the national conservation goals are unmet with some species of trees and wildlife becoming particularly endangered. Households lost the ability to complain because of their own complicity. Increased "oversight" would have been ineffective. According to Robbins, nothing will change without a change in local power relations (ibid.: 434-435, 439-440).

Consider also an experiment in Bangladesh (Crook and Manor 1998: 85-135). Here an effort to decentralize political decision-making increased corruption and 
increased the inefficiency of public works spending. According to the authors, "corruption assumed major proportions, so that the councils would need to receive huge injections of funds if significant amounts were to be left over for development after profiteering" (ibid.: 112). Based on interviews and their own observation, the authors estimate that perhaps 30 to 40 percent was stolen (ibid.: 119). Notice that if the funder wants a rate of return of $10 \%$ on its money, then the underlying project would have to earn 14 to $17 \%$. The authors attribute the high rate of corruption and theft not only to the venality of local leaders but also to the permissive attitude of higher authorities.

In Tamil Nadu in the 1980s and 1990s investments in tank irrigation systems were supported by overseas aid through procedures that encouraged the formation of local Water User Associations (WUAs). The WUA's were to contract for work, organize construction, and manage the improved systems using resources from new community rights over local resources. An outside team supported each WUA including a technical assistant, an institutional organizer, and a process documenter (Mosse1997: 268). Mosse details the caste and other conflicts in the WUAs and the way the WUAs were embedded in local social structures. They became a locus for conflict, not a site for reform. The actions of the WUAs were, according to Mosse, driven by the priorities of outsiders as much or more than the wishes of village residents.

Finally, in Indonesia, another study documents how resources were wasted through corruption and self-dealing in village-level aid projects and suggests some ways of involving the beneficiaries in monitoring the programs using existing local institutions such as local Muslim prayer groups (Woodhouse 2002). A further study of the way local communities and the state dealt with allegations of corruption in Indonesia stresses the interactions between local processes and the state. Local procedures to recover corruptly obtained funds were successful in many cases but often only because of the threat of going to the courts. Outside actors involved in the administration of aid programs or willing to provide legal help for free were often essential to persuade local people to pursue a case against powerful local individuals. Even in such cases, however, court judgments were difficult to enforce, and even if an official went to jail, the lost funds were not recovered. Because of the distance of the courts from remote villages, once a case entered the formal legal system it lost salience at the village level (World Bank 2003).

In evaluating these cases, one must, of course, recognize that money lost to corruption and self-dealing is not burnt up. It is used for something. Individual officials and their families are better off with more money in their pockets. A pure cost/benefit analysis is agnostic about who obtains the benefit and looks only at net total gains. The analyst would compare the marginal productivity of the corrupt transfers with the marginal productivity of the public project before recommending reform. However, this is, in my view, a fundamentally misguided way to approach the issue. 
If, indeed, funds are more productive in private hands, then the government should simply discontinue the program, not condone corruption. At the very least corruption and self-dealing require wasteful efforts to keep malfeasance secret, skew the distribution of benefits and costs, and encourage the use of resources to compete for rents, rather than to engage in productive activity (Krueger 1974, Rose-Ackerman 1999: 9-15, 213-215). If one cannot locate feasible anti-corruption strategies for very ineffective programs, simply canceling the program is always an option.

The cases suggest that there are two ways for grassroots involvement to limit corruption both of which appear promising. First, local households can monitor the use of central government or foreign aid funds and report to the government when they observe misuse. This can produce very large gains if the status quo is characterized by large leakages at the center. Second, local people can actually provide the services themselves under contract with an aid agency or a higher level government. Both of these options require that the public service be one that is actually desired by the local people; otherwise the benefits will be limited to jobs and supplies, and few services may be provided as people accept sinecures and walk off with materials. The options also require local organizational structures that are relatively effective and egalitarian. Even if these two conditions hold, the interaction between the grassroots and higher levels of government needs to be analyzed to be sure that empowering the local level is actually a sustainable goal. In short, these encouraging successes are not capable of mindless generalization although one can surely find other cases beyond those outlined above where they can work well.

The rich variety of experience is both encouraging and humbling. The cases indicate which factors need to be considered but can hardly produce the "blueprints" or "best practices" preferred by the international lending organizations. Existing research suggests that a number of factors must come together before government reform can succeed. Transparency and publicity are powerful tools but only if combined with grassroots organizations with the incentive and the competence to use the information provided. Outsiders can help both in providing information and in helping construct functioning local organizations. These strategies will not work, however, if state officials use intimidation and threats to keep ordinary people from engaging in oversight and political action. Formal state institutions such as the courts, the Ombudsman, a functioning Freedom of Information Act, and an independent Audit Office, need to form a backstop for efforts to make government more transparent and accountable to ordinary citizens. It does not do people much good to know what the government is doing if they are too intimidated to act on this information or if the routes for protest are blocked or ineffective. An outline for reform in this area would include both efforts to improve accountability at the grass roots in small towns and urban neighborhoods and the strengthening of central government institutions that provide accountability. 
However, even if effective programs can be designed, they cannot deal with corruption that is not subject to monitoring by individuals. I turn now to two areas where grassroots efforts are not sufficient: procurement and revenue collection.

\section{B. Procurement Reform}

Business executives worldwide believe that corruption in public procurement contracts is prevalent although there is considerable interregional and cross-country variation. The 2002 Executive Opinion Survey of the World Economic Forum shows the proportion of those surveyed who report that bribery is high/very high in various areas of business life including corruption in procurement (figure 8). Some business people report that they avoid government business for that reason (Kaufmann 2003: 8-9, Anderson, Kaufmann, Recanatini 2003: 11-13). Of course, corruption in contracting occurs in every country - even those at the high end of the honesty index such as Scandinavia, Singapore and New Zealand, but it appears more widespread and harmful in some countries than in others. ${ }^{13}$ This is partly a function of the share of business in government hands. Two countries might have corruption in $20 \%$ of all public construction contracts, but if the public sector accounts for $80 \%$ of construction in one state and $10 \%$ in another, the private construction sector's perception of the level of bribery will likely be affected by this difference.

\section{: FIGURE 8}

"Grand "corruption involving major construction projects can increase costs and distort priorities. If the cost of a project is inflated by ten percent as a result of corruption, the rate of return on many projects will fall so low as to make the project not worth pursuing. Furthermore, some projects would not be worthwhile with zero corruption; they are only on the government's agenda because of the kickbacks provided. In other cases, the project provides net benefits if payoffs are zero, and the important issue is the link between bribe payments and the rate of return on the project. Do the bribes just lower the profits earned by contractors in oligopolistic markets, or are they shifted to taxpayers? We have no good estimates of the incidence of bribes, but only under extreme conditions will contractors bear the full burden. Systemic corruption of this kind reduces competitiveness by limiting the number of bidders, favoring those with inside connections over the most efficient candidates, limiting the information available to participants, and introducing added transactions costs. If top officials, including the head of state, are concerned primarily with maximizing personal gain, they may favor an inefficient level, composition, and time path of investment. Investors' decisions may also be affected by the fact that they are dealing with political leaders.

Consider the officials' decision calculus. The impact of high-level corruption goes beyond the mere scale of public investment and lost revenue for the public budget. Top officials select projects and make purchases with little or no economic rationale. For 
example, if kickbacks are easier to obtain on capital investments and input purchases than on labor, rulers will favor capital intensive projects irrespective of their economic justification. One empirical study demonstrates that high levels of corruption are associated with higher levels of public investment as a share of GDP, less productive public investment, and lower levels of total investment (Tanzi and Davoodi 2002b). Corrupt rulers favor capital intensive public projects over other types of public expenditures and will favor public investment over private investment. They will frequently support "white elephant" projects with little value in promoting economic development. ${ }^{14}$ The demand for cement is one tip-off and might be used as a rough measure of excess public construction. For example, in Italy the annual per capita consumption of cement has been double that of the United States and triple that of Germany and Britain. A review of the "Clean Hands" corruption cases in Italy reveals that many construction projects were poorly conceived, over-priced, and had little or no justification beyond their ability to produce kickbacks (della Porta and Vannucci 1999).

Using the Italian case, Miriam Golden and Lucio Picci (2004) demonstrate that more precise measurement is possible. They use a study that finds that, across the Italian regions, corruption has a negative effect on economic growth by reducing private investment and reducing the efficiency of public investment (Del Monte and Papagni 2001). Golden and Picci provide evidence on one important type of inefficiencyexcessively costly public investment projects. They combine measures of physical public capital stock in the Italian regions with measures of cost to produce estimates of the relative efficiency and inefficiency of public spending throughout Italy. Building on research that finds that corruption and waste go together, they assume that corrupt officials encourage wasteful projects as a way of generating rents. The physical data cover a range of government capital investments in 1997, including roads, railroads, hospital beds, and number of school classrooms, combined into an index that is expressed as a ratio to the national average. They use a perpetual inventory model that adds up past capital formation and deducts assets when they reach the end of their service lives. The financial measures are then corrected for inter-regional cost differences and normalized so that the country mean is set at one. ${ }^{15}$ Overall, the physical index favors the northern part of the country, and the financial index favors the south. The ratio of the two indices is a rough measure of the relative levels of corruption and inefficiency. Figure 9 is a map of Italy with the regions shaded from dark to light with darker regions representing lower values of this measure. The index has a .82 correlation with Robert Putnam's (1993) measure of regional governments' institutional performance and a correlation of minus .66 with legal charges of high-level legislative malfeasance.

: FIGURES 9, 10

Of course, these are just indices that range from 1.7 to .2. They do not translate directly into a cost/benefit ratio. However, if the statistical work has corrected for 
other reasons for interregional variation, these results indicate that there are large potential gains either from reducing waste and corruption in the poorly performing regions or from transferring funds to the high performing regions. Unfortunately, the poorly performing regions also tend to be the poorer regions (figure 10). Hence, a shift of funds would be regressive. Nevertheless, within the group of low per capital income regions the state might announce its willingness to allocate future funds on the basis of past performance. Because the ratios are based on stocks, not flows, the state would also need to be able to calculate flows over a two or three year period. Within individual countries it could help national policymakers see where the pressure points are. In Italy regions that are more efficient (less corrupt) than expected given their income are above the regression line in figure 10.

As a thought experiment, suppose that we interpret the data as measuring productivity in the sense that one dollar spent in the region with the mean score produces one dollar's worth of output. (Of course, it is possible that the mean represents either a high or a low level of absolute output per dollar of input). Suppose we take the goal of raising the ten lowest regions up to the mean. If productivity in all these regions could be improved to equal the present country mean, this would imply that a hundred dollars invested in these regions would yield 100 dollars of output instead of $\$ 53.90$, an increase of $86 \%$. Even if omitted variables related to real resource costs explain half the difference, the increase would be over $40 \%$. Of course, the same caveat applies as with the education example above. A full cost $\backslash$ benefit analysis would need an estimate of the social benefits of spending on infrastructure. However, once again, for a given infrastructure budget, output could be increased either by relocating the funds or by reforming the production process in weak regions.

Given the work of Golden and Picci for Italy, one might replicate this work in other parts of the world to permit rough estimates of the variation over regions, states, or metropolitan areas in the productivity of public spending. These results can then be used to allocate public funds in a way that gives sub-national governments an incentive to use funds efficiently. Such a policy, however, leaves the actual reforms to the sub-national governments. Thus, we also need to consider reforms of the procurement system.

Procurement reform is a basic component of an anticorruption strategy. It should be viewed as an opportunity to rethink what the government buys as well as how it goes about making purchases. Government purchasing specifications should take account of the risk of corruption. When possible, goods sold in international markets where benchmark prices exist should be favored over custom made or state-of-the-art products. Under decentralized systems, regional and local governments can favor goods and services sold in national market. In such cases, the state can look to private market prices as benchmarks and state its specifications in terms of standard off-the-shelf items (Kelman 1990, Rose-Ackerman 1978: 132-135). 
Benchmarking can have an international dimension. Countries and subnational governments that are small relative to the markets in which they operate can make purchases of standard products in the international market. Market prices are excellent benchmarks here because the small government's own demand is unlikely to affect prices.

One way to obtain rough estimates is through data on United States trade. The Trade Research Institute calculates average prices and variances for goods using United States trade statistics and estimates the tax revenues lost to the United States from over-and under-invoicing (Pak and Zdanowicz 1994, 2002; Paul, Pak, Zdanowicz, and Curwen 1994). Because of product differentiation even within quite detailed categories, these price estimates are guesses, but they could give developing countries a starting point for negotiating with suppliers.

Benchmarking is in some tension with International Competitive Bidding (ICB) procedures whose sealed bidding process is often taken to be the presumptive standard of fairness and economic efficiency. The World Bank requires ICB, under which the lowest "evaluated" bidder must be accepted, for its infrastructure loans, and these standards have influenced the development of procurement codes worldwide. ${ }^{16}$ The process does permit non-price factors to be weighed in the final decision but requires these factors to be specified and quantified if possible. It is appropriate for a project, such as a dam, that is capital intensive, self-contained, and uses known and tested technology. However, if followed mechanically, it can lead to low quality work and collusive bid rigging. Instead, for small aid-dependent countries, the reputation of bidders could be drawn from the international arena. An international organization might keep a roster of contractors with information on their past performance. To avoid controversy, however, such a system should focus on a few key variables that are measurable and comparable across countries. Relevant indicators might include evidence of fraud, corruption, cost overruns, and time delays. The World Bank could integrate such a roster into its revised Procurement Guidelines (1999) which state that the Bank will declare firms ineligible for Bank contracts "either indefinitely or for a stated period of time" if it determines that the firm has engaged in corrupt or fraudulent practices in connection with Bank-financed projects [Section 1.15(d)]. Thus one could imagine something similar to Golden and Picci's estimates for Italy although obviously these estimates would be less precise if applied internationally.

In correspondence with the author, Lucio Picci suggested an intriguing connection between benchmarking in public procurement and citizen oversight. He pointed to the way internet services, such as eBay, provide feedback on the reputation of buyers and sellers. The feedback is entirely voluntary and is a decentralized mechanism with broad reach. Although there are obvious risks, for example, a seller with a low reputation can reenter the system under a new name, and reputations can be influenced by self-interested buyers and sellers praising themselves (Dellarocas 2003). 
Nevertheless, such a feedback mechanism might have applications to government contracting. Picci suggested that a benchmarking system organized by the central government in a country like Italy or internationally by the World Bank could provide information on the costs of various standardized infrastructure activities under different contracts. Citizens who use the services or observe the work being done could post opinions on the internet with respect to particular public works. There are obvious design problems that would have to be overcome to make such a system operational, but it seems worth study for countries with reasonably high levels of both literacy and internet access. It is not a viable option for the people at the bottom of the income ladder in some of the case studies outlined above.

Civil service reform can complement procurement reform by providing incentives to officials to perform effectively and avoid corruption. Bonuses earned by officials who achieve procurement goals could substitute for illegal payoffs. However, civil service reforms that simply raise wages to competitive levels are unlikely to be sufficient. One recent study, based on data from 35 countries, found that meritocratic recruitment was associated with measures of good bureaucratic performance, but that the role of competitive salaries was unclear (Rauch and Evans 2000). A study that examines the impact of a specific reform effort suggests a reason for the ambiguity. The study deals with a very narrow issue: hospital procurement of standardized supplies - saline solution, ethyl alcohol, iodine povidine, and hydrogen peroxide-by hospitals in Buenos Aires (Di Tella and Schargrodsky 2002). The authors studied the impact of a crackdown in which the central authorities checked the prices paid at 28 hospitals and used information of high relative prices as evidence that payoffs may have occurred. Prices decreased during the crackdown especially in the early months. Wage levels and enforcement intensity had complementary impacts except at high levels of enforcement where enforcement appeared to be a substitute for high wages. One cannot tell if these results generalize, but they do suggest that a policy of paying high wages to officials needs to be combined with a credible enforcement effort for optimal deterrence.

However, civil service reforms and enforcement against lower level officials are only necessary, not sufficient, for success in combating corruption in procurement. Scandals frequently have implicated top government leaders who profited from their inside knowledge and connections. The above proposals are not much help in dealing with such "grand corruption." They focus instead on middle level procurement decisions under the control of professional civil servants. They are, however, consistent with reforms that shift procurement decisions to career officials and tender boards. If rulers wish to insulate themselves from the demands of political supporters, they should create impartial bodies with independent procurement authority.

The basic reorientation of reforms efforts away from perfecting the bidding process toward making the overall purchasing environment more efficient and 
effective is a fundamental shift in perspective spearheaded by Kelman's work (1990, 2002). It seems an especially valuable innovation for developing countries with limited capacity to carry out complex bidding procedures. Although competitive bidding sounds like a good idea, bidding does not play a rule in a truly competitive market. Instead, the market price is set through the multiple interactions of many buyers and sellers. The World Bank does permit what it calls "shopping" for off-theshelf purchases so long multiple suppliers exist (World Bank 1999: section 3.5). My point is simply that countries should try to design their projects to favor shopping over sealed bidding as a way of limiting corruption.

Of course, frequently governments do need to make special purpose deals using a well-organized bidding process to minimize costs. Developing countries will be making large investments in special purpose infrastructure for years to come. These projects are unlikely to require sophisticated new technology, but they are one-ofa-kind. Thus the effectiveness of competitive bidding procedures will remain a central concern. Accepting the validity of the basic principles of International Competitive Bidding procedures for such projects, countries still need to assure robust competition among bidders. The same is true for competitive systems that make use of pre-screening processes. There are two problems - the possibility of collusion and the difficulty of attracting bidders. If contractors are willing to use violence to silence critics, the challenge to democratic state authority is greatest. The first order of business is then protection for whistleblowers and a willingness to follow up on allegations in a way that removes the impunity of officials. These procedures, however, must be designed to avoid encouraging people to use corruption scandals as a way to undermine one's political opponents. ${ }^{17}$

Developing countries could experiment with benchmarking, experience-rating for contractors, the adoption of more transparent processes, and civil service reform. In countries with a scarcity of skilled procurement experts and weak public accountability the case for bench marking and the purchase of standard items is strong. The cost $\backslash$ benefit calculus here requires a balance between reductions in flexibility and reductions in costs. The reduction in corruption is gained at the cost of a poorer fit between procurement specifications and the government's "needs."

\section{Customs and Tax Administration}

States cannot function if they are unable to collect taxes. A few countries rely heavily on outside grants and loans from international financial institutions, and a few still obtain considerable revenue from publicly owned enterprises. Most countries, however, require a functioning tax system. A legitimate democratic state appears to require that the state be able to collect taxes from its own citizens, not rely on outside sources of revenue. If citizens are not taxed, they have little incentive to hold the state accountable (Moore 1998). Many poor and emerging economies have very 
low capacities to collect taxes from their own citizens and from businesses and tend to collect taxes in arbitrary and unfair ways. In nearly every developing or transitional country where diagnostic surveys have been conducted, customs and tax administration are cited as loci of frequent and large unofficial payments (Anderson, Kaufmann, and Recantini 2003: 10). One consequence of an arbitrary and corrupt revenue system is to drive firms to operate at least partly off the books. The 2002 BEEPS survey in Eastern Europe and the former Soviet Union found a negative association between the percent of sales reported to tax authorities and the proportion bribing tax authorities (Fries, Lysenko, Polanec 2003: 15). Dissatisfaction with the quality of public services becomes a justification for underpayment, and underpayment produces low quality services. [See Fjeldstad and Sembola's (2001: 2069) survey in Tanzania.] Thus limiting corruption in procurement and service provision can help limit tax avoidance. However, independent corrupt incentives exist in the collection of taxes and duties, and reduction in those incentives is the theme of this section.

Businesses and individuals frequently collude with tax collectors and customs agents to lower the sums collected and expedite services. As a result, revenue collection may be both inadequate and distributed unfairly. Taxpayers and corrupt officials divide the savings in taxes and duties. The costs are born by those taxpayers who are poorer and less well-connected and by the general public in the form of reduced services.

Take just a few examples. A major scandal in China revealed that state and party officials in a major port in southern China had been entirely corrupted by smugglers with a huge loss in customs revenue (Gong 2002). In Pakistan one study estimated that if the leakages caused by corruption and mismanagement could be reduced by fifty percent, the tax to GDP ratio would increase from 13.6 to over 15 percent (Burki 1997: 16). In Bolivia a highly politicized tax administration is also viewed a very corrupt and is estimated to lose millions in tax revenues through a mixture of corruption, smuggling and informal, off-the-book businesses (Kaufmann, Mastruzzi, and Zaveleta 2003: 355). A study of efforts to reform tax administration in Mexico and Argentina points to the costs of corruption and inefficiency in the revenue system as an underlying cause of the fiscal crises of the early 1980s. The weak and arbitrary aspects of the tax system in both countries contributed to a poorly functioning public sector and inefficiencies in the private sector as well. The resulting crisis persuaded political elites of the need for reform (Berensztein 1998).

The experience of a number of African countries illustrates the magnitude of the problem. In some studies the revenue shortfall was about 50\% (Stasavage 1999: 71). In Gambia, in the early nineties, foregone revenue from customs duties and the income tax amounted to 8-9 percent of GDP (six to seven times the country's spending on health). Income tax evasion alone was 70 percent of revenue due. Only 40 percent of small and medium sized enterprises paid taxes, and many individuals 
did not file returns. Underpayment of customs was facilitated by the lack of clear guidelines and of published tariffs. The extensive discretion of officials encouraged corrupt payoffs designed to evade tariffs. Of course, a well-working system would have been able to reduce tax and tariff rates, but the distortionary effect of such a high level of evasion is clear (Dia 1996: 46-47, 94-100). A study of tariff exemptions in Zambia, Tanzania and Mali estimated that exemptions, both justified and unjustified, produced a revenue shortfall of close to 50 percent (Low 1995). In Mozambique in 1995 the customs service collected 49 percent of the revenue it would have collected if no exemptions had been given. Officials added extra delays, overestimated the value of goods, and applied higher rates in an attempt to extract payoffs (Stasavage 1999). In Zaire, much of the country's output was smuggled out with the complicity of customs officials. Corruption was also pervasive in evading import duties and controls (MacGaffey 1991). Studies of the Gambia, Mozambique, and Ghana suggest that corruption permits the rich to avoid taxes (Dia 1996; Stasavage 1999). Tax avoidance in the Philippines reputedly means that the poor contribute twice as much as the rich, and 63 percent of imports pay no duty. ${ }^{18}$

Corruption in tax and customs is not just a transfer from one pocket to another. In addition, tax burdens are distributed unfairly, and resources are lost keeping the illegal behavior secret. A corrupt tax and customs system that favors some groups and individuals over others can destroy efforts to put a country on a sound fiscal basis and discredit reform. For example, in Mozambique interviews carried out in 1996 indicated that corruption had grown since the beginning of reform efforts in 1986. Overall taxes fell from 20 percent of GDP in 1993 to 17.6 percent in 1994 with import taxes falling from 5.1 percent to 3.9 percent of GDP (Stasavage 1999). Corruption is especially common when nominal tax rates are very high (De Melo, Ofer, and Sandler 1995; Webster and Charap 1993). High nominal tax rates lead to bribes and other types of tax avoidance which lead to even more avoidance, and so forth in a vicious spiral.

One response is to repeal certain taxes that are difficult to collect and to lower overall rates. Tax reform frequently involves simplifying taxes and levying them on bases that are difficult to hide or underestimate. For business taxes, presumptive taxes can be levied that are fixed independently of a firm's actual profitability. The reduction in corruption and tax evasion is traded off against the reduction in fairness. For example, Mexico introduced an alternative minimum tax of two percent on the real value of firm assets. A firm pays the maximum of the value of this tax and the corporate tax otherwise due. Small business pays a lump-sum tax per person employed, and medium-sized businesses are taxed on turnover. All these reforms raised additional revenue through reductions in tax evasion and in corruption (DasGupta and Mookherjee 1998: 311-312). Such reforms are, however, unlikely to be sufficient if officials have no incentive to work effectively and if the state does not 
punish the underpayment of tax. For example, tax simplification in the Philippines apparently provided few benefits because there were no improvements in the incentives facing tax collectors and taxpayers (Das-Gupta and Mookherjee 1998: 410).

Reforms may produce a win \win situation where administrative costs are reduced because of tax simplification and revenue collections rise. Successful reform of a country's system of revenue collection should permit a reduction in nominal rates of tariffs and taxation. This may permit an escape from the trap where high rates lead to evasion, and evasion leads to higher nominal rates and even more evasion. A case study of India provides a classic case (Das-Gupta and Mookherjee 1998: 101-102). Despite an increase in rates, total revenue declined both because of an increase in corruption and a shift into off-the-books activity. In such cases, nothing short of a thoroughgoing reform of the structure and administration of the tax system will allow a breakthrough. Simply raising the wages of tax collectors and increasing surveillance are unlikely to be sufficient (ibid.). In contrast, Russia recently simplified its income tax system by introducing a flat $13 \%$ rate and introducing credible enforcement measures. Tax revenues have increased.

Incentive schemes have sometimes had positive effects. These can be incentives both for tax collectors and for tax payers. Das-Gupta and Mookherjee (1998: 257) report on efforts that combined the creation of a relatively autonomous bureaucracy with a budget linked, in part, to its success at collecting revenue. Reforms of revenue collection services in several African countries had similar features (Dia 1996). For example, Ghana in the eighties tried an enclave approach to tax and customs reform by creating a new National Revenue Service (NRS). Prior to the reform, tax revenues were 4.5 percent of GDP. Under the reform, the most corrupt existing officials were dismissed or retired. Pay and working conditions were improved. Increased salaries were accompanied by incentive systems to reward strong performance by individuals and by the agency as a whole. Revenue targets were established, and the NRS was given a bonus of 3.5 percent of tax revenue and 2.5 percent of customs revenue. Between 1984 and 1988 tax and customs revenue rose from 6.6 percent to 12.3 percent of GDP. Thus as long as the cost of the program did not exceed 5.7 percent of GDP, the program was a net revenue generator. The reforms illustrate the importance of combining improved base pay with incentives for good performance. Furthermore, rank and file officials must believe that corruption is rare at the senior levels. The program was a relative success, but it was not without problems. The rest of the civil service chafed at the special treatment afforded tax collectors. After all, the bonuses received by the NRS increased not only if effort increased, but also if taxes rose because of an exogenous increase in GDP. Furthermore, the Ministry of Finance objected to its loss of authority. In 1991 revenue collection was again placed under the authority of the Ministry of Finance although it retained some of its independence. Corruption reportedly increased (Chand and Moene 1999). The 
strengths and weaknesses of several African experiments with Revenue Authorities are summarized by Devas, Delay, and Hubbard (2001).

In an instructive study of a failure, Fjeldstad (2002) analyzed an unsuccessful effort to reform the Tanzanian Revenue Authority along the same lines as the Ghana case. Before reform, lost revenues were high because of illegal behavior. Up to $70 \%$ of the value of imports did not appear in official statistics, and domestic businesses underreported production volumes and profits and falsified deductions. The reform focused on the control of discretionary tax exemptions, reform of the high and complex rate structures, improved pay and working conditions for tax officials, and strengthened enforcement. As in Ghana, a semi-autonomous agency was set up with local leaders of known integrity, and most staff were fired and had to reapply and take a test. The first year 1996-1997 was a seeming success with a 30\% increase in revenue collected. However, between 1997 and 2001 corruption reemerged and revenue collection fell. The dismissed officials became "tax experts" who facilitated corrupt tax avoidance deals. Improved salaries did not deter officials. Fjeldstad points to the partial nature of reform. The tax system remained complex, non-transparent, and unclear.

One proposal is a contract with a private firm that both assesses and collects duties and then retains a fraction of the revenue collected. For example, Mozambique has experimented with such a system for customs revenues. In 1997 revenues jumped by 40 percent (Hubbard, Delay, and Devas 2001). Revenue collection has increased each year. In 2000 the contract was extended and is now set to expire at the end of 2004 (http://www.crownagents.com/). The contract is also meant to be a step toward a reformed and locally operated customs service, but that aspect of the project is behind schedule. ${ }^{19}$

Such contracts are expensive and are unlikely to provide a viable permanent solution. In the case of the customs service in Mozambique, the contractor obtains $3.5 \%$ of revenues collected but, in addition, Mozambique covered the costs of the expatriate staff. In 2003 there were 13 expatriate consultants and two short-term specialists. Overall the contract cost over $20 \%$ of projected revenues although net costs were presumably lower because the government saved money on its own bureaucracy (Hubbard, Delay, and Devas 2001). To see the implications of this fee, suppose that the reform doubles gross tax collections from $\$ 100$ to $\$ 200$. Of that, $\$ 160$ is transferred to the treasury which, I assume, also saves $\$ 10$ in collection costs for an overall revenue of $\$ 170$, which is $\$ 80$ above the old net revenue of $\$ 100$ $\$ 10=\$ 90$. The increase in net revenue from $\$ 90$ to $\$ 170$ is an increase of almost $90 \%$. Of course, these are just made-up numbers, but, in fact, gains do seem substantial in high corruption environments. Notice that in my example, if gross tax collections increased to $\$ 125$ or less with no reduction in state expenses, contracting out would not be worthwhile. Low levels of corruption should simply be tolerated in that case unless inexpensive internal reforms are an option. Note that the size of 
the bribes themselves does not figure into this calculation. The bribe is a transfer from the taxpayer or importer to the official. The social cost is the distortion introduced by the bribe in the form of reduced tax collections from bribe payers and a distorted incidence of taxes.

Durable reform should deal with the underlying incentives for tax evasion. In some countries the nominal level of taxes and duties is so high that citizens and businesses justify their evasion on the grounds that they cannot survive if they obey the law. In addition, tax laws are often complicated and unclear giving tax collectors leeway to make exceptions. These factors can produce a situation where a high proportion of households and businesses are law breakers. This gives the incumbent government a tool for controlling dissent and undermining political opponents. The goal should be a tax system with rates that can realistically be paid and with simple and clear standards. In addition, the rules must be transparent to the public, and systems of accountability must exist. If they do not, simple clear rules can simply permit a top ruler to extract payoffs more effectively. This is just one example of the importance of viewing reform in the context of the political-economic environment. Furthermore, governments can give taxpayers incentives to pay on time. The government of Mexico City, for example, is encouraging people to pay their taxes on time by giving them a discount if they file early.

Some reforms in the collection of state revenue are, in principle, costless. The goal is to reduce bureaucratic discretion, a policy that ought to both reduce bribes and reduce bureaucratic inputs. The problem is political will and the political power of those who pay and receive bribes. However, if personnel are deeply corrupt, simply changing the rules may not be sufficient. The state may need to replace officials, and new employees may need to earn higher salaries, have better working conditions, and get bonuses for good performance. Costly oversight and auditing may be necessary. One option is to contract out the collection of revenue to a private firm based in a developed country. This may increase revenue collection, but it is option and unlikely to be a feasible long term solution.

\section{Business Regulation}

A high proportion of firms surveyed in the Executive Opinion Survey in 2002 reported that the illicit purchase of laws, policies, and regulations was high/very high (see figure 8). These results appear to include both the outright purchase of general rules and corruption in the administration of existing policies. Bribery to obtain access to public utilities was also a prevalent in some regions. Corruption appears to take time. Data on Eastern Europe and the former Soviet Union indicate that the larger the share of firms that bribe public officials, the greater the proportion of senior managers' time spent dealing with public officials (Fries, Lysenko, and Polanec 2003: 16-17). The data indicate that corrupt firms usually spend more, not 
less, time dealing with authorities. Figure 11 shows that in most countries in the region, corrupt firms average more time dealing with authorities than firms that report paying few or no bribes. This result suggests that corrupt systems are ones that create red tape and vague rules as spurs to the payment of bribes.

: FIGURE 11

Corruption occurs both at the time a business is established and later as it seeks to survive. The World Bank has pioneered studies of the hurdles facing those seeking to establish and maintain business firms throughout the world. One part of this research focuses on the costs in time and money of establishing a new business legally. Building on Hernando de Soto's (1989) research in Peru, these studies show how entrepreneurship is discouraged and how those who persevere are pushed into corrupt and off-the-books operations by the tediousness and expense of complying with the law. The second strand of research begins with measures of the shares of managers' and employers' time spent dealing with government officials. This research deals only with registered companies, but it, of course, indicates one reason why firms operate in the informal or "gray" economy seeking to avoid official notice.

A simple conclusion from this research is that firms would be much more productive if the government removed the rules and regulations that make entry and operation costly. This looks like a costless reform. Firm managers and employees redirect their time to productive activities, and more firms enter the market thus increasing competitive pressures and benefiting consumers with lower prices. Some of the studies of this phenomenon take this viewpoint, and see obstacles to firm entry and operation as pure costs. Unfortunately, this conclusion is too glib. Although reformers should examine the existing rules and regulations in most countries to determine if some can be eliminated, some business/government interactions can be socially beneficial. Then the proper response is not to eliminate the program but to reform it in ways that limits corrupt incentives. However, even with such reforms some costs will remain. I have already discussed two important examples in my discussions of tax collection and procurement and their reform. In addition, rules regulating environmental pollution, waste generation and disposal, worker health and safety, unionization, the issuance of securities, consumer fraud and product safety, and so forth have solid public policy justifications even if the details of a state's actual laws are far from ideal. Some countries may have such dysfunctional state institutions that it is better not to take on some regulatory tasks until conditions improve. Others, however, may be able to institute reforms that suit their level of capacity_-similar to the simplified tax system discussed above.

This leads to a basic recommendation: Expand the diagnostic work already done to more countries but also include a more nuanced policy response that tries to sort out valuable from useless public programs. However, if reform is selective, the 
result may simply give the remaining officials more power to extract bribes. It is quite possible that the actual level of payoffs might increase as the transaction cost of corruption fall. This can still be beneficial as less time is wasted by the firm and by public officials, but remaining corrupt officials still have an incentive to facilitate market monopolization to maximize rents. The "one-stop-shops", much touted by development agencies, may simply be efficient bribe-collection agencies. Thus, in streamlining business / government relations, governments need to decide what public functions are really necessary and then construct bureaucratic procedures that limit corrupt opportunities through such devices as impersonal procedures; simple, transparent rules; inter-bureaucrat competition, effective complaints and appeals procedures; etc. (Rose-Ackerman 1999: 39-68, 146-149).

There appear to be some win \win possibilities here where dysfunctional rules and regulations can simply be repealed. The main cost is an expansion of the diagnostic work already being done by such organizations as the World Bank to include more countries and a modification of existing work to highlight the benefits of government programs that impose financial and time costs on business.

\section{E. INTERNATIONAL EFFORTS}

Multinational firms are involved in many deals with developing countries and emerging economies. If corruption is involved, the result may bring few benefits to the host country and impose costs on the multinational. This has led to international treaties to control corruption - most notably at the Organization for Economic Cooperation and Development (OECD), the Organization for American States, the Council of Europe, and, most recently, the United Nations. These documents all reflect the salience of the issue of global corruption, but none of them is very powerful as a law enforcement tool.

Their impact will depend upon their ability to change the discourse inside member countries and in the international business communities in ways that also change behavior. These treaties have so far not had much concrete impact although they do seem to have changed the dialogue over corruption in ways that have a real impact on firms that care about their reputations. However, to go further, these treaties will have an impact only when combined with strong domestic efforts in both home and host countries. I will not describe these efforts here. Those with a deeper interest in the current status of these treaties can consult the relevant websites maintained by each organization. ${ }^{20}$ I discuss several possibilities that are related to current debates and to some aspects of these international agreements. My main focus is on alternative forms of information disclosure and accountability in extractive industries. I conclude with a discussion of asset recovery initiatives.

Extractive industries (e.g. oil, minerals) are a current focus because considerable empirical evidence suggests that, when the state is weak or venal, there can be 
a resource curse in which the presence of such resources hurts economic growth by diverting energy into rent-seeking instead of productive activity (Rose-Ackerman 1999: 213-215). Paul Collier and Anke Hoeffler (2004) point the link between natural resource dependence and civil war. The management of such resources is of great importance especially in Sub-Saharan Africa which is on the verge of an oil boom and has many other poor resource-dependent countries. According to The Economist, "a handful of states are expected to receive $\$ 200$ billion in the next decade" as a result of oil and gas exploitation (December 6, 2003, p. 39).

One initiative is a campaign backed by a coalition of nongovernmental and civil society organizations called "Publish What You Pay." The campaign's goal is an international regime that requires disclosure of net taxes, fees, royalties and other payments made by natural resource companies to developing country governments. The aim is to help citizens of these countries hold their governments responsible for the use of revenues from these investments (http://www.publishwhtatyoupay.org). Of course, if the country's government is not dependent on the support of its own citizens, this can be an empty gesture that simply informs helpless citizens that their rulers are benefiting at their expense.

The second proposal is an international, multi-stakeholder effort called the Extractive Industries Transparency Initiative (EITI). The EITI includes host countries in the mix and seeks to have both sides of the transactions make public reports of legal payments. Part of the motivation for this initiative is to permit outsiders to check if there is any discrepancy between the figures reported by firms and by governments. At this point the EITI is working toward a voluntary pilot program involving a few resource dependent countries. The pilot countries are likely to be drawn from the following list: East Timor, Azerbaijan, Ghana, Trinidad and Tobago, Democratic Republic of the Congo, Indonesia and Nigeria. One idea is to use a "trusted third party", perhaps the World Bank, to develop a standardized process and to receive reports (details and updates at http://www.dfid.gov.uk). As a background report prepared for a February 2003 meeting makes clear, there are a number of problems in making the data comparable and in dealing with contracting issues, including confidentiality. Furthermore, presumably a program could go forward only if all the multinational and domestic contractors and concessionaires in an industry agree on the procedure. Thus even a "voluntary" procedure would have to have mandatory aspect as participating countries make disclosure a condition for doing business. Collier and Hoeffler (2004) discuss EITI in their Copenhagen Challenge paper as a promising option to reduce the risk of civil conflict and to fuel growth. They estimate the total discounted present value of benefits at roughly $\$ 29$ billion with trivial costs. Even if those benefit numbers are much overstated, the potential net gains look large is absolute number although they are a very small share of the discounted present value of world income. ${ }^{21}$ The main problems are the 
difficulty of specifying exactly what EITI requires and of being sure that its terms are followed. This is one example of a program with small social costs but that will impose massive losses on those in favorable positions to extract rents. Thus it will not be easy to implement.

Third are efforts that concern host country use of the funds from oil and mineral extraction. For example, the World Bank, which helped finance the Chad/Cameroon pipeline, has set up an International Advisory Group to make periodic reports on institutional capacity of Chad and Cameroon and on the ways funds are being used (http://www.gic-iag.org). The Bank also required Chad to set up an independent watchdog Revenue Oversight Committee to scrutinize how the oil money is spent. The Committee has rejected over half of the government contracts and insisted on open bidding. However, it has some weaknesses of its own with low staffing levels and tight deadlines that limit oversight (The Economist December 6, 2003, p. 39). The World Bank has made this project a test case in the effort to be sure that natural resource revenues benefit a nation's citizens. Its successes and failures are worth monitoring as project revenues begin flowing in. ${ }^{22}$ However, making natural resource payments from multinationals contingent on a country's own institutional oversight is only possible in very poor, aid dependent countries such as Chad. Other countries can simply refuse to accept loans from international financial institutions.

Nevertheless, these efforts seem worth pursuing. The initiatives are related to the OECD Treaty outlawing overseas bribery. Multinationals may hope that by supporting greater transparency, they can avoid having payments that they record as royalties or taxes end up in the personal bank accounts of leaders. They may also hope that transparency will limit the financial demands of host country officials. However, the leaders of countries that have only weak democratic institutions may not be deterred by transparency, which, although necessary for corruption control and good governance, is not sufficient. If civil society is weakly organized in the host country and lacks the expertise to understand company and country reports, transparency may have little impact inside the country. Its main role may be in putting international pressure on both firms and country leaders. This suggests that the NGOs behind the "Publish What You Pay" initiative have a point is pushing for a mandatory disclosure system managed by an international organization. The mandatory aspect of such a plan could take the form of making such disclosure by firms and governments a condition for receiving favorable investment guarantees and subsidies from home countries or from the international aid and lending organizations such as the World Bank Group, including the IFC and MIGA.

The international business community is beginning to recognize the costs of corruption to the global investment environment. Insofar as this is true, it suggests that international businesses themselves could contribute to the effort by providing funds and technical assistance to countries interested in reform. This is already being 
done through professional associations such as the American Bar Association, but the aid and lending organizations might explore the possibility of collaborative projects. For example, one aspect of the EITI is a plan to provide technical assistance to developing countries to improve their public budgeting procedures and reports. Such assistance could be underwritten by the firms that invest in the countries in question although, of course, they ought not play a direct role in the administration of such programs.

Although a wide range of options have been proposed to deal with corruption at the international level (Rose-Ackerman 1999: 177-197), I conclude with just one additional possibility, asset recovery — an important part of the new United Nations treaty. One key requirement is to make corruption a predicate offense to the application of money laundering requirements. This broadening of the definition was included in the United States Patriot Act in 2001, but it is not a universal provision of such laws. A second issue is the grounds under which assets can be frozen and ultimately turned over to the government of the country of the corrupt official. The process is often cumbersome if it works at all. Thus the Congo has had little success in retrieving Mobutu's overseas riches, and Nigeria has only recently obtained substantial sums from overseas banks that hold funds deposited their by Sami Abacha, its former ruler. Kenya's new government has decided not to prosecute its former president, in part, because of the difficulty of recovering assets. ${ }^{23}$ Enhanced asset recovery appears to depend not so much on a willingness to bear large costs as on changes in entrenched legal regimes that would require a difficult and controversial rethinking of present practices

\section{OPTIONS FOR ImPROVING Governance AND REDUCING CORRUPTION}

The operation of the state and its interaction with the public are key challenges facing the world. If government performance does not improve in many states, programs designed to help the poor, improve the natural environment, and stimulate economic growth will have little impact and risk inflicting harm.

Estimating the costs and benefits of specific reforms is difficult even if crosscountry research indicates that the gains from reducing corruption and improving governance are large. The main problem is tracing specific links from particular, concrete policies to desirable outcomes. Even the World Bank, which has been a leader in quantifying the costs of the corruption, has been unwilling to organize the data in that fashion. However, some options are almost costless. Hence, even if the benefits cannot be precisely measured, the rates of return are large. This is, of course, not to say that there are no losers. Obviously, individuals and firms, many with political power, benefit from the status quo and will oppose change. A major challenge for governance reform is to overcome or co-opt entrenched interests. 
Unresolved empirical issues limit the estimates of the relative cost-effectiveness of different strategies and the ways in which distinct alternatives interact. Thus an option may be better than the status quo but not necessarily better than another proposed reform. Furthermore, some of the options have never been tried on a large scale and have never been subject to systematic efforts to measure their effectiveness. Thus, reformers need to design experiments and pilot programs to test the value of options that appear promising. Based on my collection of reform options, there are several promising options.

OPTION I: Grassroots monitoring and service delivery with technical assistance and information provision provided centrally by government or nongovernmental organizations. Benefits: Cost savings on existing programs that have ranged as high as $400 \%$. Better overall economic performance and access of the poor to public services. Costs: Opportunity cost of people's time; costs of consultants and central government officials to help design programs and provide information. Demoralization costs if government does not respond to citizen complaints Note: Assuming the underlying program is beneficial, net benefits for successful programs are likely to be large with large benefit/cost ratios, but more needs to be learned about what works and is sustainable. Positive model cases: Brazilian urban democracy, monitoring of Uganda school funding, Nepalese local public works, South Africa Community Participation Programs.

Option 2: Procurement reform: Develop benchmarks and use them to reward efficient providers of public services. Consider integrating benchmarking with webbased reputation system based on public input. Role for international institutions, regional bodies, or central governments in providing benchmarking cost estimates and setting up interactive public comment systems. Encourage competition in providing goods and services to the state through use of more open procedures. More purchase of standardized products sold in international markets. Benefits: Cost saving on public contracts that may total $30-40 \%$ according to some estimates.

Costs: Costs of gathering benchmarking information and creating a system to use it. Note: Once again, assuming the underlying project is worthwhile, net benefits and $\mathrm{B} / \mathrm{C}$ ratios will be large with benefits many multiples of costs. The main problem is a "technical" one-no one really knows exactly how to design a viable system. Model Cases: Golden and Picci's work on Italy, Pak and Zdanowicz's estimates of over-and under-invoicing in US, United States procurement reforms in the 1990s spearheaded by Kelman.

Option 3: Reform of revenue collection through tax simplification, incentives to collectors and tax payers, monitoring. Short-term use of private firms from outside 
the country to assure integrity. Benefits: Increased revenue collection in the best cases was close to $100 \%$. Costs: Increased pay and bonuses for collectors or fees paid to outside contractors, but these seldom total more than $50 \%$ of the revenue collected. Because the costs apply to all revenue, the existing situation must be quite dire to justify these expenses. But the costs and revenue gains can be checked ex post so the policy is self-correcting. A further cost is demoralization costs imposed on other government employees who see the benefits flowing to the tax office. Note: Net benefits and B/C will be high in many cases. Either the state can lower taxes or raise the level of service provision, but either way the productivity of public spending rises. Negative model: Tanzania. Mostly positive models: Ghana, Mozambique.

Option 4: Reduction in the state-imposed costs of establishing a new business and in the costs associated with ongoing business \government relations. Regulatory cutbacks tempered with concerns for valid goals of some public regulations. Benefits: Encourages formation of new businesses and increases economic value of existing businesses. Less managerial time spent dealing with public officials. Costs: Close to zero for pure "red tape," but reformers also need to evaluate any benefits forgone from programs with some social value. Note: If reforms are designed with care, there are very high $\mathrm{B} / \mathrm{C}$ ratios and net benefits.

Option 5: International Options: Technical assistance to develop monitoring and transparency initiatives as in the Chad/Cameroon pipeline and the Extractive Industries Transparency Initiative. Enhanced asset recovery. Benefits: More of the benefits of extractive industry projects would flow to developing countries. Given the leakage in some past projects, this could increase host countries' benefits substantially. Increased risk of asset recovery could reduce the incentives to engage in corruption. These are transfer or pecuniary benefits that shift resources from multinationals and key political insiders to ordinary citizens in poor countries. However, research on the costs of corruption suggest that there are also efficiency gains as well. For example, Collier and Hoeffler (2004) estimate that the total discounted present value of a successful EITI initiative could be $\$ 29$ billion.

Costs: Administrative costs of setting up such systems which should be only a few percentage points of the value of any project. Note: Although the net benefits of EITI appear large, some technical issues have not been resolved so this is not an "off-the-shelf" option. A range of experiments could be carried out in this area involving pilot programs in vulnerable countries.

I conclude with a few thoughts about the relationship between these policy proposals and the international environment. Consider aid and lending. Presently there is an ongoing debate about the value of conditionality in the provision of aid. 
"Conditionality" in some broad sense is inevitable. International donors must choose where to put scarce funds, and they will consider where the funds will have some positive payoff. A weak state or one with high levels of corruption will be unlikely to manage aid well and so will get less. A state that does receive aid must comply with financial reporting requirements to assure that the funds are not lost to corruption and waste. Such conditionality, however, is less directly intrusive than aid that comes with explicit requirements for institutional reform. This latter type of conditionality has not been notably successful. An alternative is to organize projects that are directly focused on improved governance. For example, the Chad Revenue Oversight Committee and International Advisory Group for the Chad/Cameroon pipeline are cases in point that deserve to be carefully studied to isolate their strength and weaknesses.

I have documented some successes and some failures, but projects that improve governance and oversight seem the place to put external resources so long as a plausible exit strategy can be designed so that external funds and experts can leave with some assurance that a program will continue. A condition of such projects should be a research component that measures progress (or its opposite) by providing information on background conditions, tracking the design and implementation of the reform, and measuring outputs. Donors and country partners would try to quantify inputs and outputs in terms such as the speed and effectiveness of government activities, the satisfaction of citizens, and the distribution of benefits. Sometimes, as in a tax or procurement reform, the benefits can be quantified in terms of additional dollars collected or cost savings, but in other cases, such as more transparent government, the benefits take the form of greater citizen satisfaction and better government accountability. These factors are valuable in their own right and are associated with higher levels of growth and individual well-being, but the precise links from specific policy interventions to outcomes are not well-specified.

Recent discussions of how to allocate foreign assistance to developing countries sometimes conclude that some countries have such poorly functioning institutions that no external aid should be provided because so much of it will be lost. This represents not, as some say, an end to conditionality but is instead conditionality writ large - at the level of the country as a whole, rather than at the level of the program. The best mixture seems to be broad-based decisions about which countries to support with some share of aid taking the form of grants to improve government performance. Outsiders would not micromanage individual projects, for example, to build roads, support education, provide health care. Instead, they would supply technical assistance that could lead to a quite deep involvement with the details of government operations. In contrast, policies which try to isolate corrupt countries and individuals from the international community encourage their rulers to descend into paranoia and isolation and are ineffective ways to help the citizens of these 
countries who are the real victims of corruption. Real reform requires systemic policy initiatives. Corruption is a problem of institutional failure. A "clean hands" policy in which wealthy countries hold themselves aloof from tainted countries and individuals without doing anything actually to address the underlying problems will simply further divide the world into rich and poor blocs.

\section{NOTES}

1 Henry R. Luce Professor of Law and Political Science, Yale University. I am grateful to Madiha Afzal and Dionysia-Theodora Avgerinopoulou for very useful research help. In parts of this paper I draw on Rose-Ackerman (1999). I am grateful to Daniel Kaufmann, David Nussbaum, Luccio Picci, Martin Raiser, annd Jong-Song You for helpful comments and current references.

2 Correspondence with Daniel Kaufmann, World Bank Institute, February 2004. The World Bank Institute is preparing a document explaining the derivation of this figure and considering the relationship between the volume of bribes and the social costs of bribery.

3 Kaufman (2003, Annex 2, figures 1A, 1B, IC) presents three figures showing the postive correlations between the log of read GDP per capita and corruption, the rule of law, and voice and accountability, respectively. The governance measures are derived from survey evidence mostly based on the perceptions of business people and country experts.

4 The corruption measure is an ordinal index derived from surveys, not a cardinal measure. Thus, a move from 2 to 3 on the index might imply a greater increase in integrity on some cardinal measure, such as level of bribes per capita, compared with a move from 8 to 9 . One should not give a cardinal interpretation to indices of corruption. If a country's index fall from 6 to 3, this does not mean that corruption has been halved. However, if one compares countries at any CPI score between 2 and 4 with those between 8 and 9, there is a greater spread in the HDI levels in the former case than in the latter. There is, however, another aspect of the data that deserves mention because it determines the curvilinear shape in figure 1 The HDI uses a logarithmic scale for the income portion of the index, a technique the compresses the scale for wealthy countries. A similar graph with per capita income on the $y$-axis instead of the HDI shows a more dispersed pattern of income at higher levels of the (somewhat different) corruption index (Kaufmann 2003, figure 1A). However, at low levels of the index (that is, in highly corrupt environments) the data points continue to appear more dispersed than at high levels.

5 Neither predictability of bribe requests nor positive views of government on other questions (a "kvetch" effect) affected that conclusion and no measure of these effects was significant (Kaufmann, Mastruzzi, and Zavaleta 2003: 372-377).

6 Batra, Kaufmann, and Stone (2003: 14). The survey results were converted to binary zero/one codings with zero indicating the desirable outcome for business (ibid.: 11). A related study by Fries, Lysenko, and Polanec (2003: 40) using only data from Eastern Europe and the Former Soviet Union produced similar results. Qualitative perceptions of corruption, crime, judicial quality, regulatory constraints, taxes, and financing constraints significantly affected GDP per capita in 2001, real GDP growth from 1997-2001 and real GDP growth in 2002, all in the expected direction.

7 Entrepreneurs with the least secure property rights invest $40 \%$ less than those with the most secure property rights. At the time of the survey in 1997, the absence of bank finance did not prevent firms from investing because they were profitable enough to satisfy their investment needs internally (Johnson, McMillan, and Woodruff 2002). Although employment growth is unrelated to property rights, high sales growth is significantly associated with more secure property rights (Johnson, McMillan, and Woodruff 2000). 
8 See also Graf Lambsdorff (2003a) who concludes, using cross-country data, that legal reform, directed at the improvement of property rights and the maintenance of law and order, is crucial for attracting foreign capital.

9 Fjeldstad (2003) provides a literature review on decentralization and corruption that cites studies that contradict the results for federalism found in the sources listed in the text. In any case, it is important to distinguish between federalism and explicit policies designed to empower those at the grassroots. I discuss the latter below.

10 Of course, Suharto did actually resign from office in May 1998, but as Fisman points out, this is a difficult event to study within his framework because so many other things were happening at the same time: the "event window" was several months long, the successor was a Suharto ally, and trading volumes were exceptionally low by the end of 1997. Perhaps for these reasons, the relationship did not hold in the beginning of 1998 except for steep declines in the shares of firms controlled by Suharto's children. (Fisman 2001: 1100, note 9).

11 See, for example, table 2 in La Porta et al.(1999: 240-241). High levels of corruption are highly correlated with bureaucratic delays and low levels of tax compliance on a country by country basis.

12 For an excellent collection of articles that focus specifically on failed states see Rotberg (2003, 2004). For more on the establishment of the rule of law in weak states see Rose-Ackerman (2004) in one of Rotberg's volumes.

13 Transparency International issues a cross-country index of corruption that is a compilation of others' rankings based moatly on perceptions of the level of corruption in business dealings. New Zealand and Singapore are near the top of the list along with the Scandinavian countries, Canada Australia, and the Netherlands. The 2003 Transparency International Corruption Perception Index is available at http://www.transparency.org/surveys/index.html\#cpi. The United States Department of Justice (DOJ) prosecutes cases of corruption at all levels of government. Over the decade 1993. 2002, the DOJ obtiained 20, 497 convictions (9.821 of federal officials, 5,782 of state and local officials, and 4,894 of private citizens involved in public corrption offenses) (United State Department of Justic, 2003). Obviously some convictions were associated with the same underlying corrupt practices.

14 See Tanzi and Davoodi (2002a) for a review of empirical work on corruption, growth and public finance. A study of structural adjustment lending in seven African countries concluded that much investment spending was of dubious worth. "'White elephant' projects, inflated contracts, flight capital, and other associated ills became rampant before - and eventually contributed to - the [government fiscal] crisis in each case. A major aim of adjustment programs has been to weed out these undesirable investments (particularly in the public sector) and to improve overall efficiency (Faruqee and Husain 1994: 6).”

15 For more details see Golden and Picci (2002) who report that the overall index of physical capital is not very sensitive to the method of aggregation.

16 See World Bank (1999: 25-28) at http://web.worldbank.org/WBSITE/EXTERNAL/PROJECTS/PROCUREMENT/O, contentMDK:20060840 pagePK:84269 piPK:60001558 theSitePK:84266,00.html. The World Trade Organization's (WTO) Agreement on Government Procurement and related documents are available at http: / / www.wto.org.

17 As an example, see “Treacherous Roads," The Economist December 20, 2003, p. 56. The article reports on the murder of a young engineer employed by the state of Bihar in India to manage part of a highway project. He sent a letter to the Indian Prime Minister outlining a list of “dodgy practices". The letter was leaked to the relevant contractors, and the engineer then received threats. The authorities did not respond, and the engineer was eventually shot and killed.

18 Far Eastern Economic Review April 20, 1996.

19 For example, a 2002 report pointed to problems in achieving this goal. See http://www.u4.no/projects/projects.cfm?id=103.

20 OECD Convention on Combating Bribery of Foreign Public Officials in International Business Transactions, December11,1997, http://www.oecd.org/document/21/0,2340,en_2649_34859_2017813_1_1_1_1,00.html. Council of Europe, Criminal Law Convention on Corruption, Jan uary 27, 1999, E. T. S. 173 (entered into force 2002), http://conventions.coe.int/Treaty/EN/Treaties/Html/173.htm and http://www.greco.coe.int/docs/ResCM(1999)5E.htm, 
Inter-American Convention Against Corruption, March 29, 1996, 35 I.L. M. 724 (entered into force March 6, 1997, available at http://www.oas.org/main. United Nations Convention Against Corruption, Dcember 9, 2003, available at http://www.unodc.org/unodc/crime_convention_corruption.html.

21 World income in 2002 was $\$ 32.2$ trillion. Even supposing no growth in the total, the discounted present value of a 10 year stream at this level, discounted at $5 \%$ is $\$ 248.6$ trillion. The estimated benefits of EITI are .012 per cent of that total.

22 "Greasing the Engines of Change in Chad," The New York Times, February 18, 2004.

23 “Kenya Joins Nations Pursuing Funds Stolen by Ex-Leaders," New York Times, December 21, 2003.

\section{BIBLIOGRAPHY}

ABERS, Rebecca 1998. "From Clientalism to Cooperation: Local Government, Participatory Policy, and Civic Organizing in Port Alegre, Brazil,” Politics and Society 26: 511-537.

ACEMOGLU, Daron 2003. “The Form of Property Rights: Oligarchic vs. Democratic Societies,” draft, Department of Economics, MIT, Cambridge MA, September.

ACEMOGLU, Daron, Simon Johnson, and James A. Robinson 2001. "The Colonial Origins of Comparative Development: An Empirical Investigation,” American Economic Review 91:1369-1401.

ADAMS, Charles F., Michael E. Bell, and Trevor Brown. 2002. "Building Civic Infrastructure: Implementation Community Partnership Grant Programmes in South Africa," Public Administration and Development 22:293-302. ADES, Alberto, and Rafael Di Tella. 1997. "National Champions and Corruption: Some Unpleasant Interventionist Arithmetic,” The Economic Journal 107:1023-1042.

ADES, Alberto, and Rafael Di Tella. 1999. "Rents, Competition, and Corruption," American Economic Review 89:982-993.

ANDERSON, Christopher J., and Yuliya V. Tverdova. 2003. "Corruption, Political Allegiances, and Attitudes Toward Government in Contemporary Democracies,” American Journal of Political Science 47: 91-109.

ANDERSON, James, Daniel Kaufmann, Francesca Recanatini. 2003, "Service Delivery, Poverty and Corruption - Common Threads from Diagnostic Surveys," background paper for 2004 World Development Report, Washington DC: World Bank. June 27. www.worldbank.org/wbi/governance/capacitybuild/d-surveys.html. ANDVIG, Jens Christian. 1995. "Corruption in the North Sea Oil Industry: Issues and Assessments," Crime, Law, and Social Change 28: 289-313.

ANECHIARICO, Frank, and James B. Jacobs. 1996. The Pursuit of Absolute Integrity: How Corruption Control Makes Government Ineffective, Chicago: University of Chicago Press.

BARDHAN, Pranab. 1997. “Corruption and Development: A Review of Issues,” Journal of Economic Literature 35: 1320-1346.

BATRA, Geeta, Daniel Kaufmann, and Andrew H. W. Stone. 2003. "The Firms Speak: What the World Business Environment Survey Tells Us about Constraints on Private Sector Development,” in G. Fields and G.

Pfefferman, eds., Pathways Out of Poverty: Private Firms and Economic Mobility in Developing Countries, Amsterdam: Kluwer Academic Publishers, chapter 9. http://www.worldbank.org/wbi/governance/pubs/firmsspeak.html. BEHRMAN, Jere. 2003. "Labor Markets in Developing Countries," in Orley Ashenfelder and David Card, Handbook of Labor Economics, volume 3B, chapter 43.

BLAKE, Charles H., and Christopher G. Martin 2002. "Combating Corruption: Reexamining the Role of Democracy," paper presented at the Annual Meeting of the Midwest Political Science Association, Chicago, April 25-28. BROWN, Trevor. 2001. "Contracting Out by Local Governments in Transitioning Nations: The Role of Technical Assistance in Ukraine,” Administration and Society 32: 728-755.

BURKI, Shahid Javed. 1997. “Governance, Corruption and Development: The Case of Pakistan.” Paper presented at the Workshop on Governance Issues in South Asia, Yale University, New Haven CT, November 19.

BUSCAGLIA, Jr., Edgardo, and Maria Dakolias. 1996. Judicial Reform in Latin American Courts: The Experience in Argentina and Ecuador, World Bank Technical Paper No. 350, Washington DC: World Bank.

CHAND, S.K. and Karl O. Moene. 1999. "Controlling Fiscal Corruption," World Development 27: 1129-1140. CIOCCHINI, Francisco, Erik Durbin, and David T.C. Ng. 2003. "Does Corruption Increase Emerging Market Bond Spreads?” Journal of Economics and Business 55: 503-528. Available at http://www.sciencedirect.com. 
COLLIER, Paul, and Anke Hoeffler. 2004. "The Challenge of Reducing the Global Incidence of Civil War," Oxford University, Oxford UK, draft, January.

CROOK, R. C., and J. Manor. 1998. Democracy and Decentralization in South Asia and West Africa: Participation, Accountability and Performance. Cambridge UK: Cambridge University Press.

DAS GUPTA, Arindam, and Dilip Mookerjee 1998. Incentives and Institutional Reform in Tax Enforcement: An Analysis of Developing Country Experience, Delhi: Oxford University Press.

DAS GUPTA, Monica, Helene Grandvoinnet, and Mattia Romani. 2000. "State-Community Synergies in Development: Laying the Basis for Collective Action” draft, World Bank, Washington DC.

DELLA PORTA, Donatella and Alberto Vannucci. 1999. Corrupt Exchange. New York: Aldine. De Melo, Martha, Gur Ofer, and Olga Sandler. 1995. "Pioneers for Profit: St. Petersburg Entrepreneurs in Services,” World Bank Economic Review 9:425-450.

DELLAROCAS, Chrysanthos. 2003. "The Digitalization of Word of Mouth: Promise and Challenges of Online Feedback Mechanisms," Management Science 49: 1407-1424.

DEL MONTE, Alfredo, and Erasmo Papagni. 2001. "Public Expenditure, Corruption, and Economic Growth: The Case of Italy," European Journal of Political Economy 17: 1-16.

DE MELO, Martha, Gur Ofer, and Olga SAndler. 1995. "Pioneer for Profit: St. Petersburg Entrepreneurs in Services," World Bank Economic Review 9: 425-450.

DE SOTO, Hernando. 1989. The Other Path:The Invisible Revolution in the ThirdWorld, New York: Harper and Row. DE SOUSA SANTOS, Bonaventura. 1998. "Participatory Budgeting in Porto Alegre: Toward a Redistributive Democracy," Politics and Society 26: 461-510.

DEVAS, Nick, Simon Delay and Michael Hubbard. 2001. "Revenue Authorities: Are They the Right Vehicle for Improving Tax Administration?" Public Administration and Development 21:211-222.

DIA, Mamadou. 1996. Africa's Management in the 1990s and Beyond: Reconciling Indigenous and Transplanted Institutions, Washington DC: The World Bank.

DI TELLA, Rafael, and Ernesto Schargrodsky. 2002. "The Role of Wages and Auditing During a Crackdown on Corruption in the City of Buenos Aires," in Donatella della Porta and Susan Rose-Ackerman, eds. Corrupt Exchanges: Empirical Themes in the Politics and Political Economy of Corruption, Frankfurt: Nomos Verlag. A longer version is in Journal of Law and Economics 46: (2003).

DOLLAR, David, Mary Hallward-Driemeier, and Taye Mengiste. 2003. "Investment Climate and International Integration," draft paper prepared for Conference on the Future of Globalization, Yale Center for the Study of Globalization, October 11, Washington DC: World Bank.

EASTERLY, William. 2001. The Elusive Quest for Growth: Economists' Adventures and Misadventures in the Tropics Cambridge MA: MIT Press.

ESTY, Daniel, and Michael Porter 2002. "National Environmental Performance Measurement and Determinants" in Daniel Esty and Peter K. Cornelius, eds., Environmental Performance Measurement: The Global Report 2001-2002, NY: Oxford University Press.

FISMAN, Raymond. 2001. "Estimating the Value of Political Connections," American Economic Review 91: 1095-1102. FJELDSTED, Odd-Helge. 2002. Fighting Fiscal Corruption: The Case of the Tanzania Revenue Authority, Chr. Michelsen Institute Working Paper 2002:3, Bergen, Norway.

FJELDSTED, Odd-Helge. 2003. Decentralisation and Corruption: A Review of the Literature U4 Report, Chr. Michelsen Institute, Bergen, Norway.

FJELDSTED, Odd-Helge, and Joseph Semboja. 2001. "Why People Pay Taxes: The Case of the Development Levy in Tanzania,” World Development 29: 2059-2074.

FRIEDMAN, Eric, Simon Johnson, Daniel Kaufmann, and Pablo Zoido-Lobaton 2000. "Dodging the Grabbing Hand: The Determinant of Unofficial Activity in 69 Countries," Journal of Public Economics 76: 459-493.

FRIES, Steven, Tatiana Lysenko, and Saso Polanec. 2003. The 2002 Business Environment and Enterprise Performance Survey: Results from a Survey of 6,100 Firms,"Working Paper No. 84, European Bank for Reconstructions and Development, London, November.

GOLDEN, Miriam, and Lucio Picci. 2004. "Proposal for a New Measure of Corruption Illustrated Using Italian Data," draft 4, UCLA and University of Bologna, March. Available at http://www.spbo.unibo.it/picci/article.pdf. GONG, Ting 2002. "Dangerous Collusion: Corruption as a Collective enture in Contemporary China," Communist and Post-Communist Studies 35: 85-103.

GRAF LAMBSDORFF, Johann. 2003a. "How Corruption Affects Persistent Capital Flows," Economics of Governance 4: 229-243.

GRAF LAMBSDORFF, Johann. 2003b. “How Corruption Affects Productivity," Kyklos 56: 457-474.

GUPTA, Sanjeev, Hamid R. Davoodi, and Rosa Alonso-Terme. 2002. "Does Corruption Affect Income Inequality and Poverty," Economics of Governance 3: 23-45. 
GUPTA, Sanjeev, Hamid R. Davoodi, and Erwin R. Tiongson. 2001. "Corruption and the Provision of Health Care and Education Services,” in Arvind K. Jain, ed., The Political Economy of Corruption, London: Routledge. HUBBARD, Michael, Simon Delay, and Nick Devas. 1999. "Complex Management Contracts: The Case of Customs Administration in Mozambique," Public Administration and Development 19: 153-163.

HELlMAN, Joel S., Gereint Jones, and Daniel Kaufmann. 2003. “'Seize the State, Seize the Day': State Capture, Corruption, and Influence in Transition," Journal of Comparative Economics 31:751-773.

HELLMAN, Joel S., and Daniel Kaufmann 2004. "The Inequality of Influence," in János Kornai and Susan RoseAckerman, eds. Building a Trustworthy State in Post-Socialist Transition, New York: Palgrave, pp. 100-118. HUBBARD, M. E. V., S. Delay, and C. N. Devas. 2001. "Revenue Authorities: Are They the Right Vehicle for Improving Tax Administration?” Public Administration and Development 21:211-222.

JOHNSON, Simon, Daniel Kaufmann, John McMillan, and Christopher Woodruff. 2000. Why do firms hide? Bribes and unofficial activity after communism, Journal of Public Economics, 76: 495-520.

JOHNSON, Simon, John McMillan, and Christopher Woodruff 2002. "Property Rights and Finance" American Economic Review 92: 1335-1357.

JOHNSON, Simon, John McMillan, and Christopher Woodruff. 2000. "Entrepreneurs and the ordering of institutional reform: Poland, Slovakia, Russia and Ukraine Compared" Economics of Transition, 8: 1-36.

JOHNSTON, Michael 2002. "Comparing Corruption: Participation, Institutions, and Development," prepared for a conference on Corruption: Public and Private, John Jay College of Criminal Law, New York, August. KAUFMANN, Daniel 1997. "The Missing Pillar of Growth Strategy for Ukraine: Institutional and Policy Reforms for Private Sector Development,” in Peter K. Cornelius and Patrick Lenain, eds. Ukraine: Accelerating the Transition to Market, Washington: IMF, pp. 234-275.

KAUFMANN, Daniel 2003. "Rethinking Governance: Empirical Lessons Challenge Orthodoxy," Discussion draft, World Bank, Washington DC.

KAUFMANN, Daniel, and Aart Kraay. 2002. “Growth without Governance,” Economia 3: 169-229 (2002).

KAUFMANN, Daniel, Massimo Mastruzzi, and Diego Zaveleta 2003. "Sustained Macroeconomic Reforms, Tepid Growth: A Governance Puzzle in Bolivia," in Dani Rodrik, ed., In Search of Prosperity: Analytic Narratives on Economic Growth, Princeton NJ: Princeton University Press.

KELMAN, Steven 1990.Procurement and Public Management: The Fear of Discretion and the Quality of Government Performance, Washington DO: AEI Press.

KELMAN, Steven. 2002. "Remaking Federal Procurement," Public Contract Law Journal 31: 581-622.

KRASTEV, Ivan, and Georgy Ganev. 2004. "The Missing Incentive: Corruption, Anticorruption, and

Reelection,” in János Kornai and Susan Rose-Ackerman, eds., Building a Trustworthy State in Post-Socialist Transition, New York: Palgrave.

KRUEGER, Anne. 1974. “The Political Economy of a Rent-Seeking Society,” American Economic Review 64:291-303.

KUNICOVA, Jana. 2002. “Are Presidential Systems More Susceptible to Political Corruption?” draft, Pasadena CA: California Institute of Technology.

KUNICOVA, Jana, and Susan Rose-Ackerman. 2003. "Electoral Rules as Constraints on Corruption," draft, New Haven CT: Yale University Department of Political Science.

LA PORTA, Rafael, Florencio Lopez-de-Silanes, Andrei Shleifer, and Robert Vishny 1999. "The Quality of Government," Journal of Law, Economics, and Organization 15: 222279.

LI. HONGYI, Lixin Colin Xu, and Heng-Fu Zou 2000. "Corruption, Income Distribution, and Growth," Economics and Politics 12:155-182.

LI, Wei. 2002. "Corruption and Resource Allocation: Evidence from China," in Donatella della Porta and Susan Rose-Ackerman, eds. Corrupt Exchanges: Empirical Themes in the Politics and Political Economy of Corruption, Frankfurt: Nomos Verlag.

LOW, Patrick. 1995. Preshipment Inspection Services, World Bank Discussion Paper 278, Washington DC.

MACGAFFEY, Janet. 1991. The Real Economy of Zaire: The Contribution of Smuggling and Other Unofficial Activities to National Wealth, Philadelphia: University of Pennsylvania Press.

MANZETTI, Luigi 1999. Privatization South American Style, Oxford: Oxford University Press.

MAURO, Paolo 1995. “Corruption and Growth,” Quarterly Journal of Economics, 110:681-712.

MAURO, Paolo 1997. "The Effects of Corruption on Growth, Investment, and Government Expenditure: A

Cross-Country Analysis" in Kimberly Ann Elliott, ed., Corruption and the Global Economy, Washington: DC:

Institute for International Economics, pp.83-108.

MEAGHER, Patrick, Kumar Upadhyaya, and Betty Wilkinson 2000. Combating Rural Public Works Corruption: Foodfor-Work Programs in Nepal, IRIS Center Working Paper No. 239, University of Maryland, College Park MD, February. Available at http: //www.iris.umd.edu/publications.asp. 
MILLER, Terry. 1997. “Kelman's Latest Proposal and Past Performance Explored," Federal Computer Market Report, 21(11): 7 (June 9).

MILLER, William L., Åse Grødeland, and Tatyana Y. Koshechkina 2001. A Culture of Corruption: Coping with Government in Post-Communist Europe, Budapest: Central European University Press.

MILLER, William L., Åse Grødeland, and Tatyana Y. Koshechkina 2002."Values and Norms versus Extortion and Temptation," in Donatella della Porta and Susan Rose-Ackerman, eds. Corrupt Exchanges: Empirical Themes in the Politics and Political Economy of Corruption, Frankfurt: Nomos Verlag.

MOORE, Mick 1998. "Death without Taxes: Aid Dependence, Democracy, State Capacity, and Aid in the Fourth World," in Mark Robinson and Gordon Whites, eds., The Democratic Developmental state: Politics and Institutional Design, Oxford: Oxford University Press.

MOSSE, David. 1997. "The Ideology and Politics or Community Participation,” in R. Grillo and R. Stirrat, eds., Discourses of Development: Anthropological Perspectives Oxford: Berg, pp. 255-291.

NICHOLS, Philip M. 2001. "The Fit Between Changes in the International Corruption Regime and Indigenous Perceptions of Corruption in Kazakhstan," University of Pennsylvania Journal of International Economic Law 22: 863-973. OLSON, Mancur 1996. "Big Bills Left on the Sidewalk: Why Some Nations Are Rich and Others Poor," Journal of Economic Perspectives 10:3-24.

PAK, Simon J., and John S. Zdanowicz. 1994. "A Statistical Analysis of the U.S. Merchandise Trade Data Base and Its Uses in Transfer Pricing Compliance and Enforcement," Tax Management Transfer Pricing Report 3:50-57, May 11. PAK, Simon J., and John S. Zdanowicz. 2002. U.S. Trade with the World: An Estimate of 2001 Lost U.S. Federal Income Tax Revenues Due to Over-Invoiced Imports and Under-Invoiced Exports, Trade Research Institute, Miami FL.

PARKER, Andrew N., Decentralization: The Way Forward for Rural Development? Policy Research Paper 1475, World Bank, Agriculture and Natural Resources Department, Washington DC, June 1995.

PASUK Phongpaicht and Sungsidh Piriyarangsan. 1994. Corruption and Democracyin Thailand, Bangkok: The Political Economy Centre, Faculty of Economics, Chulalongkorn Univerisity.

PAUL, Karen. Simon Pak, John Zdanowicz, and Peter Curwen. 1994. "The Ethics of International Trade: Use of Deviation from Average World Price to Indicate Possible Wrongdoing,” Business Ethics Quarterly 4:29-41.

PUTNAM, Robert. 1993. Making Democracy Work: Civic Traditions in Modern Italy, Princeton: Princeton University Press.

RAUCH, James E., and Peter B. Evans, 2000. "Bureaucratic Structure and Bureaucratic Performance in Less Developed Countries,” Journal of Public Economics 75: 49-71.

REINIKKA, Ritva, and Jakob Svensson, 2002. "Measuring and Understanding Corruption at the Micro Level," in Donatella della Porta and Susan Rose-Ackerman, eds. Corrupt Exchanges: Empirical Themes in the Politics and Political Economy of Corruption, Frankfurt: Nomos Verlag.

REINIKKA, Ritva, and Jakob Svensson, 2004a. "Local Capture: Evidence from a Central Government Transfer Program in Uganda," Quarterly Journal of Economics 119 (2).

REINIKKA, Ritva, and Jakob Svensson, 2004b. "The Power of Information: Evidence from a Newspaper Campaign to Reduce Corruption,” Policy Research Working Paper Series, World Bank, Washington DC. ROBBINS, Paul. 2000. "The Rotten Institution: Corruption in Natural Resource Management," Political Geography 19: 423-443.

RODRIK, Dani 2003. "Growth Strategies,", forthcoming Handbook of Economic Growth, draft, Kennedy School of Government, Cambridge MA: Harvard University. Available at http://ksghome.harvard.edu/ .drodrik.academic.ksg/growthstrat 10.pdf.

ROSE-ACKERMAN, Susan. 1978. Corruption: A Study in Political Economy. New York: Academic Press.

ROSE-ACKERMAN, Susan. 1999. Corruption and Government: Causes, Consequences and Reform. Cambridge UK: Cambridge University Press.

ROSE-ACKERMAN, Susan. 2002. "'Grand' Corruption and the Ethics of Global Business," Journal of Banking and Finance 26: 1889-1918.

ROSE-ACKERMAN, Susan. 2004. "Establishing the Rule of Law," in Robert Rotberg, eds. When States Fail: Causes and Consequences. Princeton NJ: Princeton University Press, pp. 182-221.

ROTBERG, Robert, ed. 2004. When States Fail: Causes and Consequences. Princeton NJ: Princeton University Press. ROTBERG, Robert, ed. 2003. State Failure and State Weakness in a Time of Terror, Washington DC: The Brookings Institution.

SANDHOLTZ, Wayne, and William Keotzle 2000. "Accounting for Corruption: Economic Structure, Democracy, and Trade," International Studies Quarterly 44: 31-50.

SELIGMAN, Mitchell. 2002. "The Impact of Corruption on Regime Legitimacy: A Comparative Study of Four Latin American Countries," Journal of Politics 64: 408-433.

SHLEIFER, A., and R. Vishny. 1993, "Corruption," Quarterly Journal of Economics 108: 599-617. 
SLINKO, Irina, Evgeny Yakovlev, and Ekaterina Zhuravskaya 2004. "Effects of State Capture: Evidence from Russian Regions," in Janós Kornai and Susan Rose-Ackerman, eds. Building a Trustworthy State in Post-Socialist Societies, NY: Palgrave, pp. 119-132.

STASAVAGE, David. 1999. "Causes and Consequences of Corruption: Mozambique in Transition," Commonwealth and Comparative Politics 37: 65-97.

STELLA, Peter. 1992. Tax Farming - A Radical Solution for Developing Country Tax Problems? IMF Working Paper, WP/92/70, Washington DC: IMF.

STEVES, Franklin, and Alan Rousso. 2003. "Anti-corruption Programmes in Post-Communist Transition Countries and Changes in the Business Environment, 1999-2002,”Working Paper No. 85, European Bank for Reconstruction and Development, London.

SVENSSON, Jakob. 2003. "Who Must Pay Bribes and How Much? Evidence from a Cross Section of Firms," Quarterly Journal of Economics 118: 207-30.

SWAMY, Anand, Stephen Knack, Young Lee, and Omar Azfar 2001. "Gender and Corruption,” Journal of Development Economics 64: 25-55.

TANZI, Vito, and Hamid Davoodi. 2002a. "Corruption, Growth, and Public Finance" in Georege T. Abed and Sanjeev, eds., Governance, Corruption, and Economic Performance, Washington DC: International Monetary Fund, pp. 197-222.

TANZI, Vito, and Hamid Davoodi. 2002b. "Corruption, Public Investment and Growth," in Georege T. Abed and Sanjeev, eds., Governance, Corruption, and Economic Performance, Washington DC: International Monetary Fund, pp. 280-299.

TORGLER, Benno 2003. “Tax Morale in Central and Eastern European Countries," prepared for the Conference on "Tax Evasion, Trust, and State Capacity," University of St. Gallen, St. Gallen, Switzerland, October 17-19. TREISMAN, D. 2000. "The Causes of Corruption: A Cross-National Study," Journal of Public Economics 76: 399-457. United States, Department of Justice, Criminal Division, Public Integrity Section. 2003. Report to Congress on the Activities and Operations of the Public Integrity Section for 2002, Washington DC.

USLANER, Eric M. 2003.“Tax Evasion, Trust, and the Strong Arm of the Law," prepared for the Conference on “Tax Evasion, Trust, and State Capacity,” University of St. Gallen, St. Gallen, Switzerland, October 17-19. VAN RIJCKEGHEM, Caroline, and Beatrice Weder. 2001. "Bureaucratic Corruption and the Rate of Temptation: Do Wages in the Civil Service Affect Corruption, and by How Much?," Journal of Development Economics 65: 307-331.

WEBSTER, Leila M., and Joshua Charap. 1993. The Emergence of Private Sector Manufacturing in St. Petersburg, World Bank Technical Paper 228, World Bank, Washington DC.

WEI, Shang-Jin. 2000. "How Taxing is Corruption on International Investors?", Review of Economics and Statistics, 82:1-11.

World Bank. 1999. Guidelines Procurement under IBRD Loans and IDA Credits, Washington DC: World Bank, January, http: / / web.worldbank.org/WBSITE / EXTERNAL/PROJECTS /PROCUREMENT/O, contentMDK:20060840 pagePK:842 69 piPK:60001558 theSitePK:84266,00.html.

World Bank 2003. Village Justice in Indonesia: Case Studies on Access to Justice, Jakarta, draft September. WOODHOUSE, Andrea. 2002. Village Corruption in Indonesia: Fighting Corruption in the World Bank's Kecamatan Development Program, report to the World Bank, Washington DC, June.

World Bank, 1997. Helping Countries Combat Corruption: The Role of the World Bank, Poverty Reduction and Economic Management Network. Washington DC.

YOU, Jong-Song and Sanjeev Khagram 2004 "Inequality and Corruption,"Working Paper RWP04-001, Kennedy School of Government, Harvard University, Cambridge MA.

Susan Rose-Ackerman

Henry R. Luce Professor of Jurisprudence, LaW School and Political Science at Yale University 
GRÁFICOS E TABELAS

FIGURE 1: HUMAN DEVELOPMENT INDEX AND CORRUPTION PERCEPTIONS INDEX Source: CALCulated From UNDP and TRANSPARENCY INTERnational data.

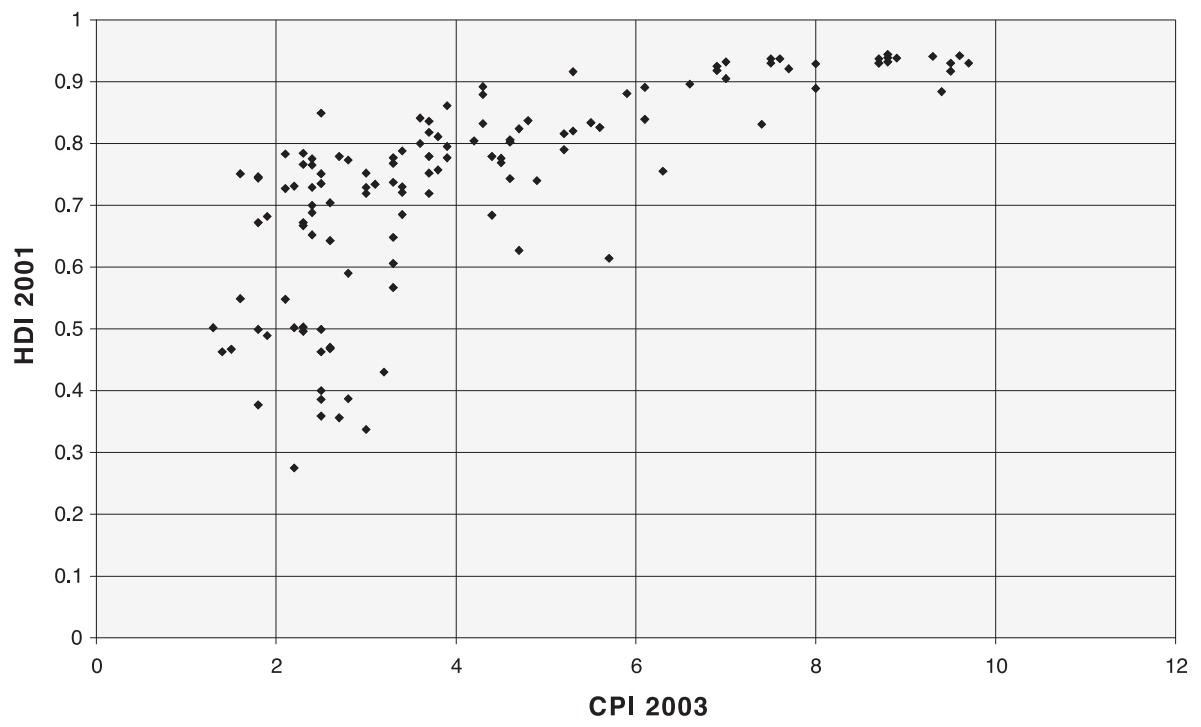

Revista Direito GV, São Paulo, p. 207-266, 2005. Edição especial 1. 
FIGURE 2: KEY BUSINESS ENVIRONMENT CONSTRAINT TO THE FIRM: EMERGING ECONOMIES AND OECD SOURCE: KAUFMANN (2004)



Source: Executive Opinion Survey 2003. Question 13.01.

From the following list, please select the five most problematic factors for doing business in your country, and rank them between 1 (most problematic) and 5 . The figure shows the percent of firms ranking the said constraint as the most problematic among the 14 items on the list. 
TABLE 1: CITIZENS' FEELINGS ABOUT GIVING MONEY OR A PRESENT

Source: Miller, Grodeland, and Koshechima (1998, TAble 23)

Q103: Suppose people gave money or a present to an official and got what they wanted, would they be most likely to feel...

Q104: But if they thought very few other people gave such things to officials, would they then be most likely to feel...

\begin{tabular}{rrrrrrrrr} 
& Czech Republic & \multicolumn{2}{c}{ Slovakia } & \multicolumn{2}{c}{ Bulgaria } & \multicolumn{2}{c}{ Ukraine } \\
& & & & & & & & \\
& 103 & 104 & 103 & 104 & 103 & 104 & 103 & 104 \\
happy & $\%$ & $\%$ & $\%$ & $\%$ & $\%$ & $\%$ & $\%$ & $\%$ \\
angry & 50 & 15 & 63 & 18 & 66 & 36 & 55 & 22 \\
worried & 25 & 36 & 23 & 37 & 13 & 20 & 11 & 24 \\
ashamed & 7 & 15 & 5 & 14 & 11 & 16 & 18 & 34 \\
a & 18 & 34 & 8 & 31 & 11 & 29 & 16 & 20
\end{tabular}

Note: 'don't know', 'mixed/depends' etc. answers were recorded if given spontaneously, but never prompted; they have been excluded from the calculation of percentages. 
FIGURE 3: THE UNOFFICIAL ECONOMY AND CRONY BIAS (DATA FROM WORLDWIDE SURVEY, 2003) SOURCE: KAUFMANN (2004)

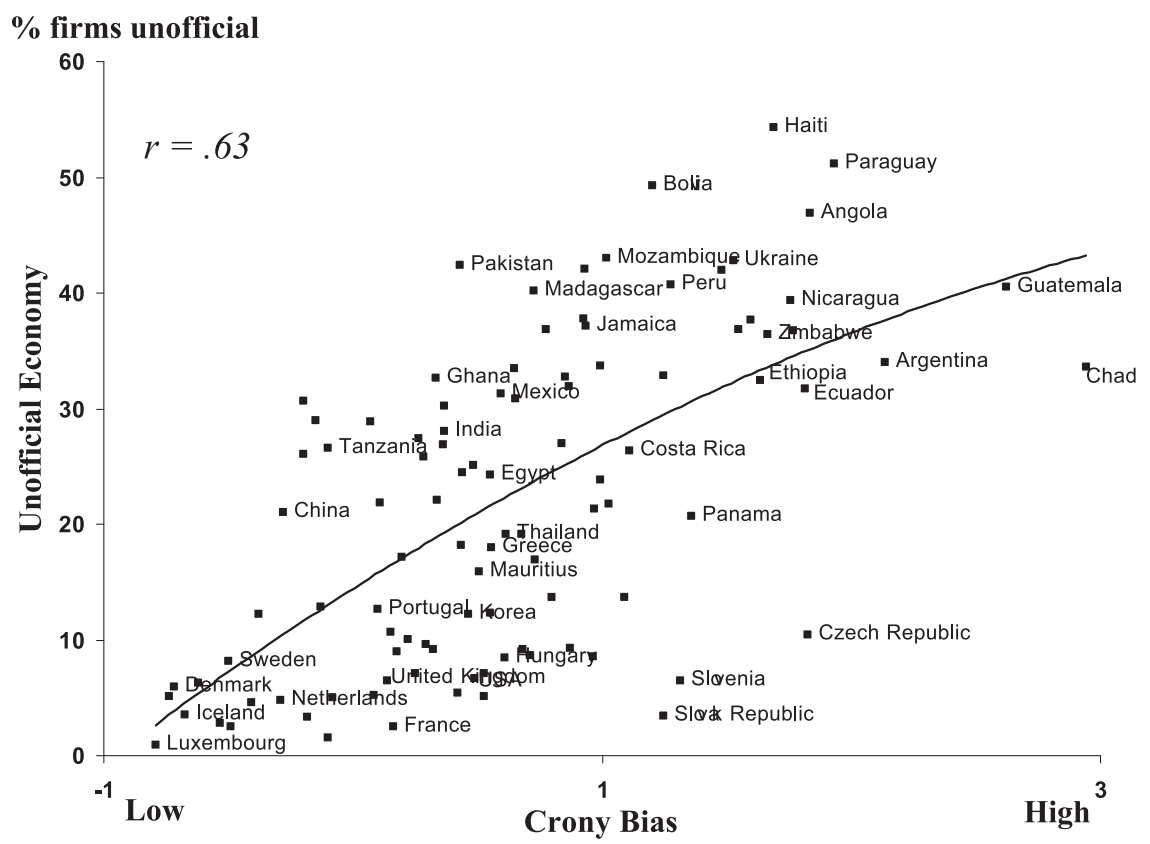

Note: Only selected countries among the 102 are labeled due to space limitations. Unofficial economy data drawn from firms' responses to following question: What percentage of business in your country would you guess are unofficial or unregistered? (categorical, converted using minimum within each range). Crony bias is constructed by authors, based on data from the 2003 Survey of firms in 102 countries, calculated as the difference between influence by firms with political ties and influence by the firm's own business association. 
FIGURE 4: CRONY BIAS AND VOICE AND ACCOUNTABILITY SOURCE: KAUFMANN (2004)



Crony bias defined in note of Figure 5 and text. Voice and accountability variable from Kaufmann, Kraay, and Mastruzzi (2003). 
FIGURE 5: VOICE AND ACCOUNTABILITY AND PER CAPITA INCOMES

SOURCE: KaUfMANN (2003)

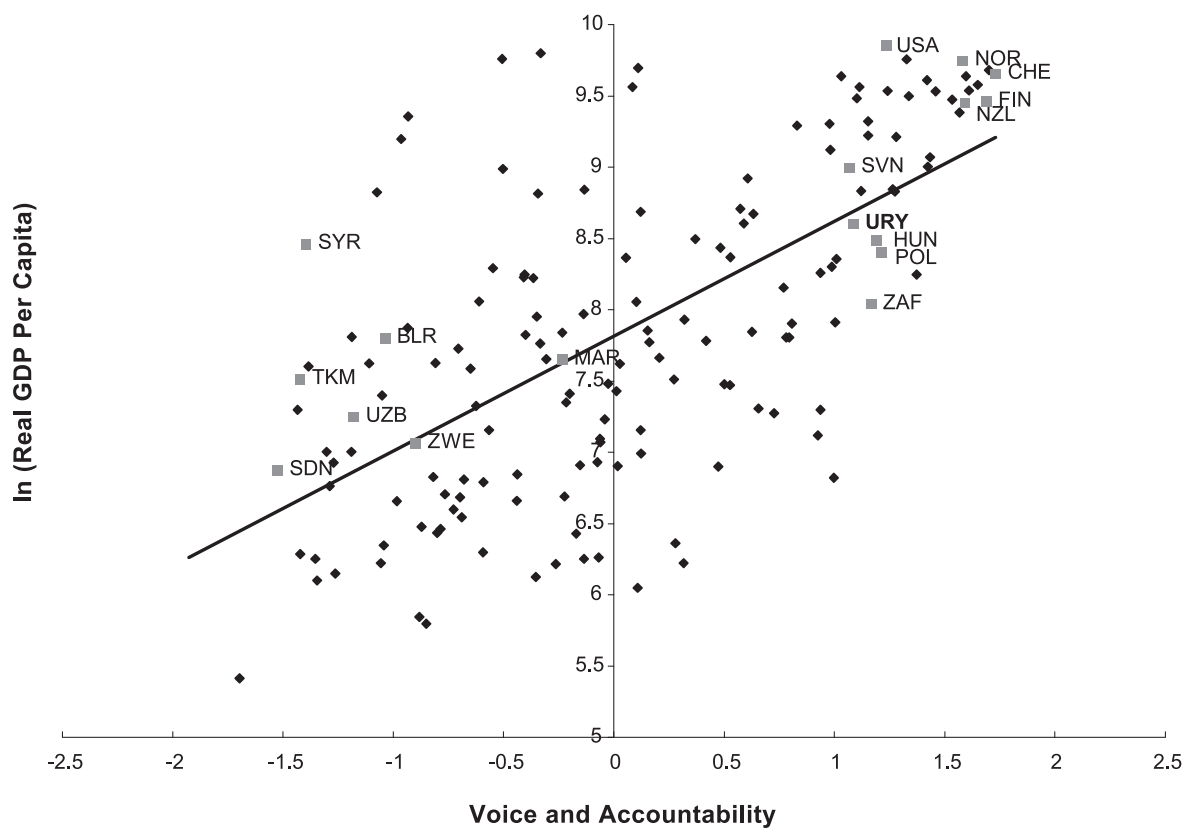

Notes: This figure plots a measure of voice and accountability in 2000/01 (on the horizontal axis) against real per capita GDP in 1995 (on the vertical axis). The governance ratings on the vertical axis are based on subjective assessments from a variety of sources, are subject to substantial margins of error, and in no way reflect the official view of the World Bank, its Executive Directors, or the countries they represent. 
FIGURE 6: EXTERNAL ACCOUNTABILITY/FEEDBACK IMPROVE ACCESS OF THE POOR TO PUBLIC SERVICES (BOLIVIA GAC DIAGNOSTIC)

SOURCE: KAUFMANN (2003)



The sample of institutions includes 44 national, departmental, and municipal agencies that provide services to the poor. Each point depicts an institution. 
FIGURE 7: UNBUNDLING CORRUPTION - EXECUTIVE OPINION SURVEY (GCR) REGIONAL AVERAGES, 2002 SOURCE: KAUFMANN (2003)

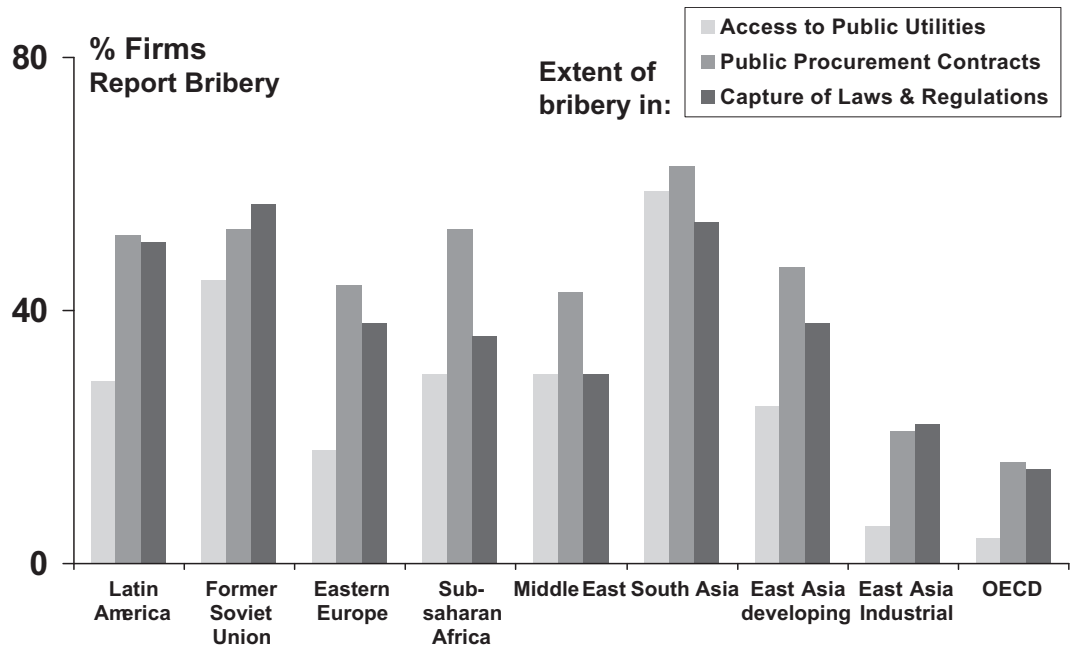

$\%$ of firms rate type of corruption as high/very high 
FIGURE 8: MAP OF PROPOSED LEVEL OF CORRUPTION BY REGION, C.1997.

SOURCE: GOLDEN AND PICCI (2004)

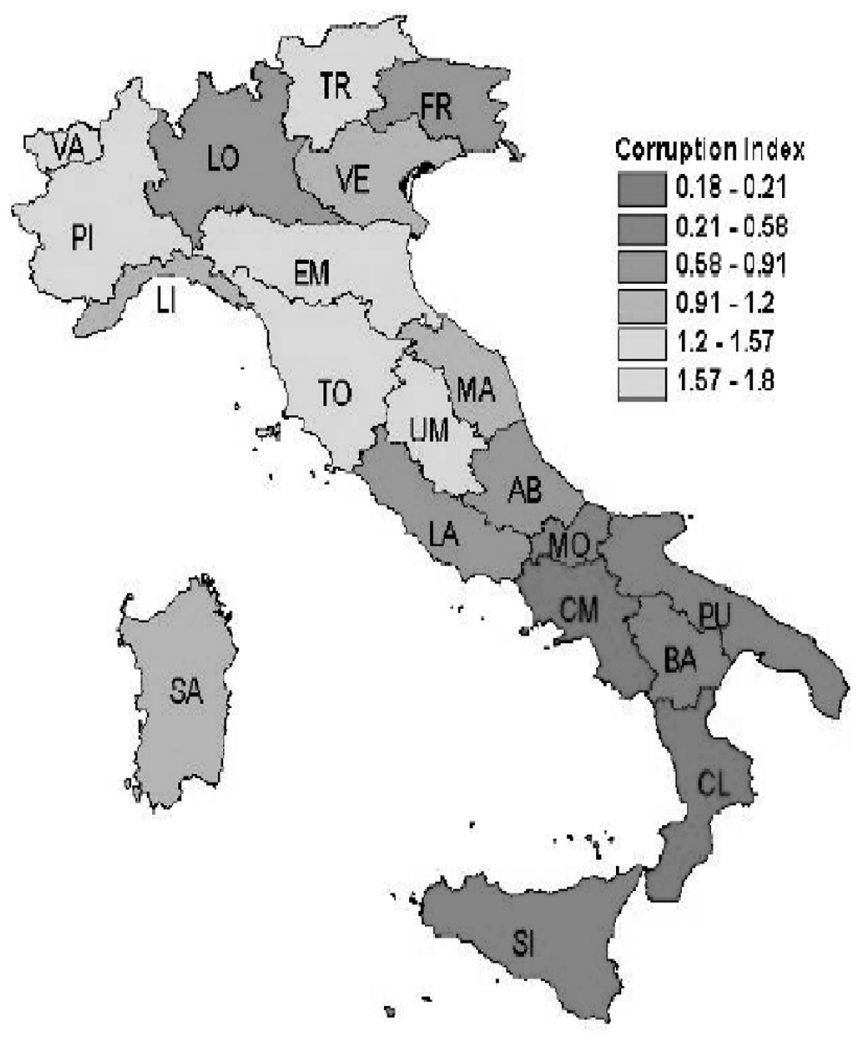

Revista Direito GV, São Paulo, p. 207-266, 2005. Edição especial 1. 
FIGURE 9: CORRUPTION AND PER CAPITA INCOME - ITALY SOURCE: GOLDEN AND PICCI (2004)

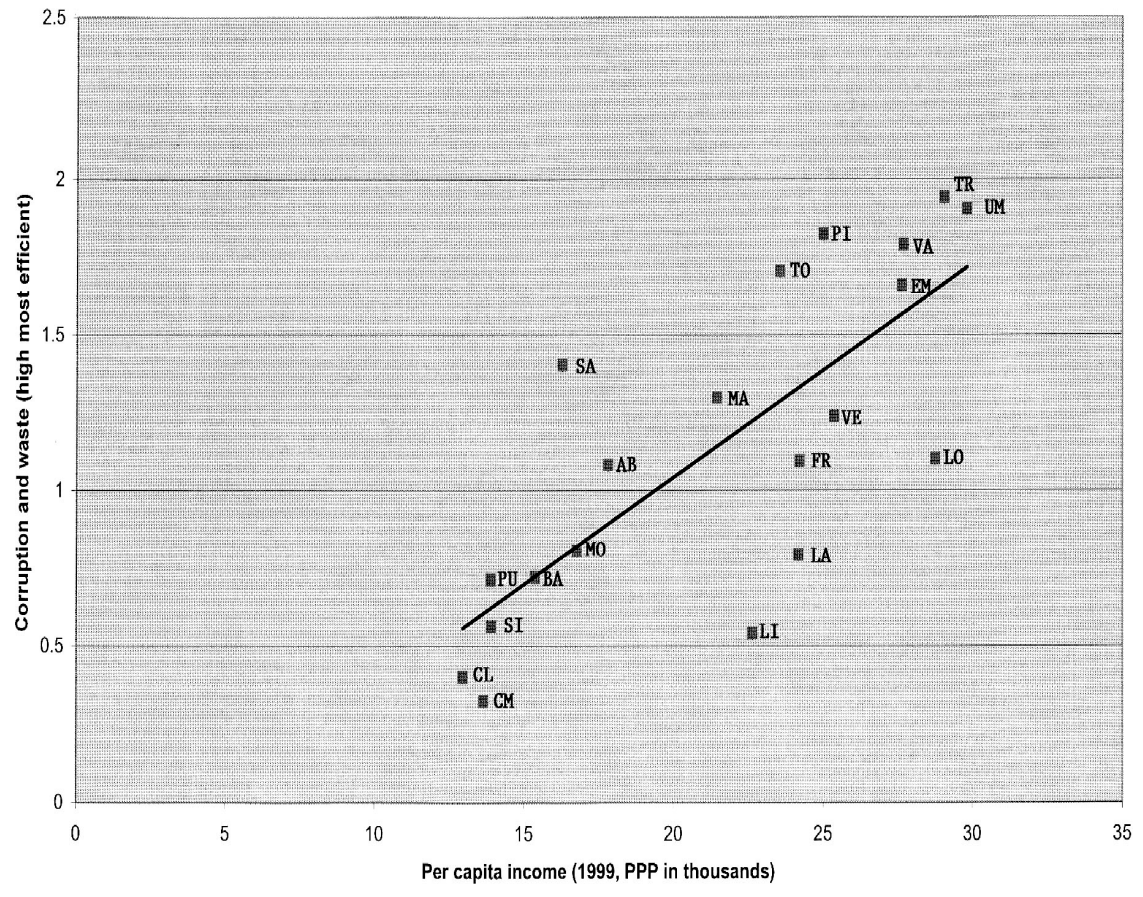

Revista Direito GV, São Paulo, p. 207-266, 2005. Edição especial 1. 
FIGURE 10: AVERAGE TIME TAX FOR FIRMS PAYING BRIBES TO PUBLIC OFFICIALS AND FOR FIRMS NOT PAYING BRIBES, BY COUNTRY

SOURCE: GOLDEN AND PICCI (2004)

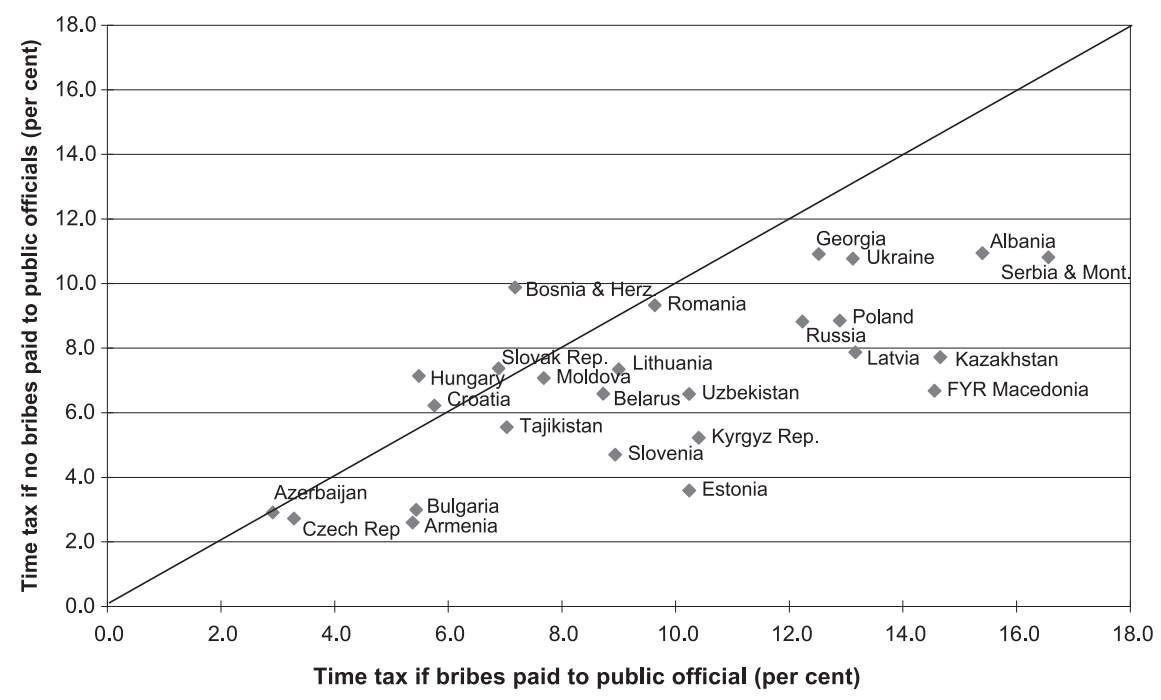

Note:

1) Time tax is calculated for each country as an unweighted average of individual firms' responses on the proportion of senior managements' working time spent dealing with public officials. The averages are calculated separately for those firms that bribe frequently or more to deal with public officials in areas of business regulation and those that do not. 